\title{
Developing The Acceptance Scale of LEGO Robotics Instructional Practices: Validity And Reliability Studies
}

\author{
Barış ÇUKURBAŞI*a, Gamze YAVUZ KONOKMAN ${ }^{\mathrm{b}}$, Bekir GÜLER ${ }^{\mathrm{c}}$, Seçil Eda \\ KARTAL $^{\mathrm{c}}$
}

\section{Article Info}

DOI: $10.14686 /$ buefad. 337738

\begin{tabular}{ll}
\hline \multicolumn{2}{l}{ Article History: } \\
Received $\quad 11.09 .2017$ \\
Revised $\quad 29.12 .2017$ \\
Accepted $\quad 30.01 .2018$ \\
\hline Keywords: \\
LEGO, \\
Robotic, \\
Technology Acceptance Model, \\
Scale Development, \\
LEGO Mindstorms \\
\hline Article Type: \\
Research Article
\end{tabular}

\begin{abstract}
In the scope of the study it was aimed to develop the acceptance scale of LEGO robotics instructional practices to determine the prospective teachers' acception of LEGO robotics instructional practices. Scale development study was carried out with the help of 360 prospective teachers having been educated at Bartin University during the 2016-2017 academic semester. Before testing form of the scale was applied to the prospective teachers, they had been introduced on LEGO Mindstorms EV3 set and how to integrate these sets into learning and teaching process. Item analysis studies were done with the correlational analysis method and the factor structure of the scale was determined with the exploratory and confirmatory factor analysis methods. Both exploratory and confirmatory factor analysis studies indicated the scale had one factor and four components. The components of the scale was called as perceived benefit, perceived easy use, intention to use and attitude. Cronbach Alpha reliability parameter of the whole scale was found as .956 and Cronbach Alpha reliability parameters of the components of the scale were found respectively as $.924 ; .929 ; .834, .915$. Exploratory and confirmatory factor analysis studies as well as Cronbach Alpha parameters indicated the acceptance scale of LEGO robotics instructional practices has been a reliable and valid data collection tool.
\end{abstract}

\section{LEGO Robotik Öğretim Uygulamalarının Kabulü Ölçeğinin Geliștirilmesi: Geçerlik ve Güvenirlik Çalıșmaları}

\begin{tabular}{|c|c|}
\hline \multicolumn{2}{|c|}{ Makale Bilgisi } \\
\hline \multicolumn{2}{|c|}{ DOI: 10.14686/buefad.337738 } \\
\hline \multicolumn{2}{|c|}{ Makale Geçmişi: } \\
\hline Geliş & 11.09 .2017 \\
\hline Düzeltme & 29.12 .2017 \\
\hline Kabul & 30.01 .2018 \\
\hline \multicolumn{2}{|c|}{$\begin{array}{l}\text { Anahtar Kelimeler: } \\
\text { LEGO, } \\
\text { Robotik, } \\
\text { Teknoloji kabul modeli, } \\
\text { Ölçek geliştirme, } \\
\text { LEGO Mindstorms }\end{array}$} \\
\hline $\begin{array}{l}\text { Makale Tü } \\
\text { Araştırma }\end{array}$ & akalesi \\
\hline
\end{tabular}

*Corresponding Author: bariscukurbasi@gmail.com

${ }^{a}$ Asst. Prof. Dr., Bartın University, Bartın/Turkey, http://orcid.org/0000-0002-2856-2676

b Asst. Prof. Dr., Bartın University, Bartın/Turkey, http://orcid.org/0000-0003-2272-1549

${ }^{c}$ Res. Asst., Bartın University, Bartın/Turkey, http://orcid.org/0000-0002-5713-4347

d Asst. Prof. Dr., Bartın University, Bartın/Turkey, http://orcid.org/0000-0002-3238-7049
$\ddot{O} \mathbf{z}$

Çalışma kapsamında öğretmen adaylarının LEGO Robotik öğretim uygulamalarını benimseme ve kabul etme durumlarını belirlemek için "LEGO Robotik Öğretim Uygulamalarının Kabulü” ölçeğinin geliştirilmesi amaçlanmıştır. Ölçek geliştirme çalışması 2016-2017 öğretim yılında Bartın Üniversitesi Eğitim Fakültesi 3. ve 4. sınıflarında öğrenim gören 360 öğretmen adayıyla gerçekleştirilmiştir. Ölçek deneme formu öğretmen adaylarına uygulanmadan önce çalışma grubunun tamamına LEGO Mindstorms EV3 ve LEGO Mindstorms EV3 setinin öğrenme öğretme süreçlerinde

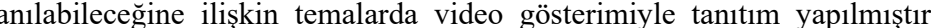
Madde analizi çalışmaları korelasyona dayalı analiz yöntemiyle gerçekleştirilmiş; ölçeğin faktör yapısı açımlayıcı ve doğrulayıcı faktör analizi çalışmalarıyla ortaya konmuştur. Açımlayıcı ve doğrulayıcı faktör analizi çalışmaları ölçeğin tek faktörlü dört bileşenli bir yapıya sahip olduğunu göstermektedir. Ölçek bileşenleri algılanan fayda, algılanan kullanım kolaylığı, tutum ve kullanıma yönelik niyet olarak adlandırılmıştır. Ölçeğin bütününe ilişkin hesaplanan Cronbach Alpha güvenirlik katsayısı .956; ölçeğin bileşenlerine ilişkin Cronbach Alpha güvenirlik katsayıları ise sırasıyla .924; .929;.834 ve .915 olarak hesaplanmıştır. Açımlayıcı ve doğrulayıcı faktör analizi çalışmaları ile hesaplanan Cronbach Alpha değerleri LEGO robotik öğretim uygulamalarını kabulü ölçeğinin geçerli ve güvenilir bir veri toplama aracı olduğunu göstermektedir. 


\section{Introduction}

Education, which is aimed to contribute to the personal development of individuals and help them to gain a certain status in the society, has to update itself continuously according to changing circumstances as in other systems regulating social life. This process of update has resulted in the adoption of modern educational approaches, as required by the 21 st century, instead of conventional practices from the materials used to the assessment - evaluation methods employed. This has manifested the requirement that the new curricula developed must be flexible, appealing / interesting and creative so that learners will be more knowledgeable and productive (Erbaş and Demirer, 2015). Furthermore, today's learners are digital natives (Prensky, 2001) and their learning characteristics have been changing, which have required major changes in education - teaching processes (Pala and Erdem, 2015). Thus, practices by which technology is integrated to education have started to come into prominence with new curricula. The use of technology in education has concentrated on the mentioned subjects, especially after constructivist learning and student- oriented learning have become the focus of interest in today's educational environments (Uğur Erdoğmuş and Çağlltay, 2013). Moreover, technology - supported instructional practices offer great opportunities in respect of the implementation of teaching theories, and technological developments increase the opportunity of learning with a constructivist approach (Karagiorgi and Symeou, 2005). Today's practices in which individuals construct the course content in their minds through concrete materials, learning by doing is considered important and learner autonomy is supported are seen as the elements that will contribute to the achievement of expected learning outcomes as a result of learning - teaching activities. Educational technologies stand as one of the practices to be used in its context, and an idea of education in which the education - teaching process is not supported by using many different types of technology seems almost impracticable (Spector, 2016).

Educational technology involves an integration between the teaching approach and technology (Koehler, Mishra, Kereluik, Shin and Graham, 2014). In other words, educational technology is a systematic approach towards education - teaching processes with a view to plan, realize and evaluate education - teaching processes in the best manner (Alkan, 2011). Educational technology also involves disciplined application of knowledge so as to improve learning, teaching or performance (Spector, 2016). Numerous educational technologies with various characteristics are used in today's world. Augmented reality, virtual reality, adaptive learning environments, online learning, wearable technology, mobile learning, new generation learning management systems, natural user interfaces, Internet tools, flipped classroom model are some of the developing educational technologies which are commonly used today. (NMC, 2017; Johnson et al., 2016; Adams Becker et al., 2016; Johnson, Adams Becker, Estrada and Freeman, 2015). In addition to the mentioned technologies, educational robotic practices are among the major developing technologies in field of educational technologies (Johnson et al., 2016; Benitti, 2012).

Educational robotic practices are an instructional strategy based on the use of robots for instructional purposes (Catlin, 2012). Study materials designed for educational robotic practices are usually prepared in such a manner that they will assist learners in their learning (Ospennikova, Ershov and Iljin, 2015). Educational robotic practices attract students' attention (Prensky, 2010) and increase their motivation (Ortiz, 2015). Moreover, educational robotic practices form creative environments (Catlin, 2012) and ensure improvement of computational thinking skills (Kazimoglu, Kiernan, Bacon and Mackinnon, 2012). LEGO Mindstorms robotic practices are among today's popular instructional practices which are commonly used in learning and teaching processes.

LEGO products are a kind of toy consisting of interlocking blocks in various colors, which can be joined together to construct a model. LEGO products are effective elements increasing students' interest in the course and enabling them to learn while having fun (Sungur, 2013). In addition to such elements, the products containing ultrasonic, auditory, tactile sensors, servo motors and a programmable piece (e.g. EV3 Brick) are called as LEGO Mindstorms products. Programming of the model created with the LEGO Mindstorms products to fulfill the predetermined functions (usually by using the LOGO programming language) is referred to as educational LEGO robotic practices (LEGO practices). The literature review addresses a large number of studies worldwide on the use of LEGO practices for learning and teaching process. Upon the review, it has been observed that LEGO practices contribute to the learning - teaching process in the following ways:

- The learner takes an active role in the process (Kazez and Genç, 2016).

- They have a positive effect on the motivation of learners for learning and taking part in the class. (Ortiz, 2015; Aufderheide, Krybus and Witkowski, 2012, Murillo, Masteo, Castellanos and Montano, 2011). 
- They assist learners in their learning by doing, through testing, experiment and design (Somyürek, 2015).

- They help learners by contributing to their development of positive attitudes towards the course (Özdoğru, 2013).

- They are effective in enabling learners to improve their problem solving skills (Castledine and Chalmers, 2011)

- They provide opportunity for teamwork and have an effective function in improving collaborative learning skills of learners. (Aufderheide, Krybus and Witkowski, 2012).

- They contribute to learners' development of attitudes towards the course (Beisser, 2005).

- They have a positive effect on the academic success of learners (Strawhacker and Bers 2015; Murillo, et al., 2011)

- They contribute to the development of learners' scientific process skills (Çayır, 2010).

LEGO practices are widely used in the teaching - learning process. In this process towards achievement of objectives, it is important that teachers and learners are interested in and enthusiastic about robotic practices. Especially for the robotic practices intended for use in the class, it is of high importance that instructors who have an important role in the process of necessary planning, design and implementation are eager / intentioned to use LEGO robotic instructional practices, the studies to be carried out are ensured to be effective and LEGO robotic instructional practices are performed. This is evidenced by results of the examination on the roles of instructors in LEGO robotic instructional practices under the studies conducted. (Mcknight, 2015; Ortiz, 2015; Strawhacker and Bers 2015). Consequently, it is revealed that there is need to examine whether preservice teachers who are likely to have the role of an instructor in robotic instructional practices are eager / intentioned to use LEGO robotic instructional practices. The results of such examination point out to the technology acceptance model.

The Technology Acceptance Model (TAM) is a quite widely used technological model (Hsia, 2016). The TAM is aimed to determine individuals' levels of acceptance of the relevant technology on basis of the criteria 'perceived ease of use' and 'perceived usefulness' (Teo, 2010; Davis, 1989); perceived ease of use and perceived usefulness are addressed as the primary markers of the TAM (Khee, Wei and Jamaluddin, 2014; Davis, 1989). Perceived usefulness is referred to as the opinion that the individual's own work/effort/skill, etc. performance will be improved in frame of the relevant topic after using the relevant technology; while perceived ease of use is referred to as the opinion that the individual can use the relevant technology by spending very little effort (Hsia, 2016). It is stated under the model that an individual's perceived ease of use and perceived usefulness in respect of a technology have an effect on determining the attitude of such individual towards using the relevant technology; that the individual's attitude towards the use of technology directly influences, while perceived ease of use and perceived usefulness indirectly influences, such individual's intention to use technology (Dastjerdi, 2016). Depending on the intention towards using the relevant technology, the individual will develop a behavior to use the technology (Davis, 1993).

It is seen upon the literature review that there are no studies on the TAM performed in Turkey, and there are very few studies on the same subject worldwide. Some of these studies are seen to be related to the LEGO robotic instructional practices while some others are seen to be related to robotic practices in different fields. A study by Chesney (2006) focused on the acceptance of entertainment - oriented software (EOS) systems. In this frame, a scale developed on the acceptance of EOS systems was applied to 68 individuals who use the LEGO Mindstorms products. It is seen from the study that the perceived usefulness for the EOS systems is the predominant criterion in deciding upon the perceived ease of use, and that the perceived ease of use does not have a direct effect on the intention towards use. Nevertheless, it is indicated that alternative EOS systems should be addressed as users may have more intention to use alternative EOS systems. In the study performed by Shih et al (2011), it was aimed to develop an assessment tool to estimate, explain and enhance students' levels of acceptance of LEGO Mindstorms NXT according to the TAM. The sample group of the study consists of 69 primary students who previously used LEGO Mindstorms NXT set. Data collection was performed by means of the 'acceptance of LEGO Mindstorms NXT set according to the TAM' scale and 'perception of self-efficacy' scale. As a result of the research, it was stated that the students' acceptance of LEGO Mindstorms NXT set were in conformity with the TAM. Shih, Chen, Chen and Hsin (2012) examined effectiveness of the use of LEGO Mindstorms NXT for the programme on fight 
against natural disasters. In this frame, users' intentions to use the LEGO products were examined via TAM. A total of 172 persons from primary school level to college level, who previously used the LEGO Mindstorms NXT set, constitute the participants of the study. Data were collected through a survey developed by the researchers. As a result of the research, it was stated that acceptance status of the use of LEGO in line with the determined purpose was determined according to the TAM. Moreover, it was stated that the perceived ease of use is statistically not significant, and that the perceived usefulness, attitude towards use and intention towards use have a high level of significance. Heerink, Krose, Evers and Wielinga (2006) used a robotic technology called iCat in their study, whereby they examined the elderly users' acceptance levels of robots and their attitude towards robots, and the effect of robots on their social skills. The study was conducted with 28 elderly participants at elderly care institutions. Data collection was performed through observation, interview and survey. As a result of the study, it was stated that the TAM does not have a high level of effect on social skills, and that elderly users have a good level of attitude towards robots.

When the literature is reviewed in terms of the levels of acceptance of the LEGO robotic instructional practices, it is seen that the studies conducted are related to former versions (RCX and NXT) of the LEGO Mindstorms products, and they examine levels of acceptance of the LEGO products in relation to a certain topic. Upon the literature review, no study was found in scope of which the LEGO Mindstorms EV3 products were used in instructional practices and preservice teachers' levels of acceptance of the LEGO robotic instructional practices were examined; there is need for research on these topics.. Therefore, the research aimed to develop the "Acceptance of LEGO Robotic Instructional Practices" scale in order to identify preservice teachers' levels of acceptance of the LEGO Robotic instructional practices. İ is considered that the scale developed in line with this aim will contribute to the literature and the assessment tool developed will be helpful for future studies. In addition, a curriculum containing robotic instructional practices was prepared by the Ministry of National Education (MEB) in scope of the Computer Sciences course at secondary school level (MEB, 2016). General objectives of the curriculum of Computer Science course include ensuring the students are "equipped with basic knowledge about robot programming", they "gain technical experience about programming", and "develop an understanding of algorithm design and express it verbally and visually" (MEB, 2016). Furthermore, it is stated that a robot programming unit is available in scope of the course and robot kits can be used (MEB, 2016). In this frame, it is believed that it is of significance to examine levels of acceptance by preservice teachers, as teachers of the future, of the LEGO practices, which are among instructional robotic practices. In this way, the scale developed in scope of the research is expected to contribute to the field.

\section{Method}

The research aimed to develop the "Acceptance of LEGO Robotic Instructional Practices" scale in order to identify preservice teachers' levels of acceptance of the LEGO Robotic instructional practices. In line with this aim, a study was performed to develop an assessment tool for the literature which will be valid and reliable.

\section{Participants}

The scale development study was conducted with 360 preservice teachers in the 3rd and 4th years of their undergraduate education at the Faculty of Education, Bartın University in the academic year 2016 - 2017. 180 of the preservice teachers $(50 \%)$ study at Science Teaching programme, $84(23,4 \%)$ at Classroom Teaching programme, $29(8 \%)$ at Mathematics Teaching programme and $67(18,6 \%)$ at Social Sciences Teaching programme. In line with the requirement that the size of sample group must be at least five times higher than the number of observed variances (Büyüköztürk, 2002; Child, 2006), it can be concluded that the number of participants is adequate for the use of factor analysis technique for the scale development study.

\section{Data Collection Process and Analysis}

\section{Preparation of the Scale Test Form}

Opinions of 5 experts from the Department of Computer and Instructional Technologies, 3 experts from the Department of Educational Sciences and 1 expert from the Department of Turkish Education were received with regard to the items of the scale test form, which was created after the literature review on the technology acceptance model and LEGO robotic instructional practices. The scale test form was examined by experts in frame of variances such as the extent to which the items comprise the variance to be assessed, conformity of the items with the factor or factors to be assessed, expression of the items in a comprehensible and clear manner, conformity of 
the items with the study group, etc.. On basis of expert opinions, some items were omitted from the scale form while some were revised in line with expert opinions. Following this process, the same experts were asked to provide their opinions by which the final version of the scale test form was created. The test form contains 26 items and the form was designed as a 5-point Likert type scale. Categories of the scale were ascertained as follow: "Strongly disagree (1)", "Disagree (2)", "Partially agree (3)", "Agree (4)" and "Strongly agree (5)".

The scale test form was applied to preservice teachers studying at the Faculty of Education, Bartın University in the fall semester of the academic year 2016 - 2017. 2 LEGO Mindstorms EV3 Education sets, available for use in LEGO robotic instructional practices, were used for this process of application. One of the sets was kept in available condition for robot design while the other set was used by the researchers to design a robot. Additionally, an exemplary LEGO robotic instructional practice was demonstrated by the researchers, taking into consideration the instructional plans of undergraduate programs subject to application. Furthermore, the designs created by the relevant researchers were generally used in relation to the LEGO robotic instructional practices. During the implementation process, a demonstration was made to preservice teachers regarding the LEGO Mindstorms EV3 set; the preservice teachers watched a 5-minute video prepared by the researchers, on how the LEGO Mindstorms EV3 set can be used in learning - teaching processes. Following the demonstration and the video presentation, LEGO set box and preservice teachers were shown the theme site materials and provided with brief information about how the robot was designed (Picture 1).

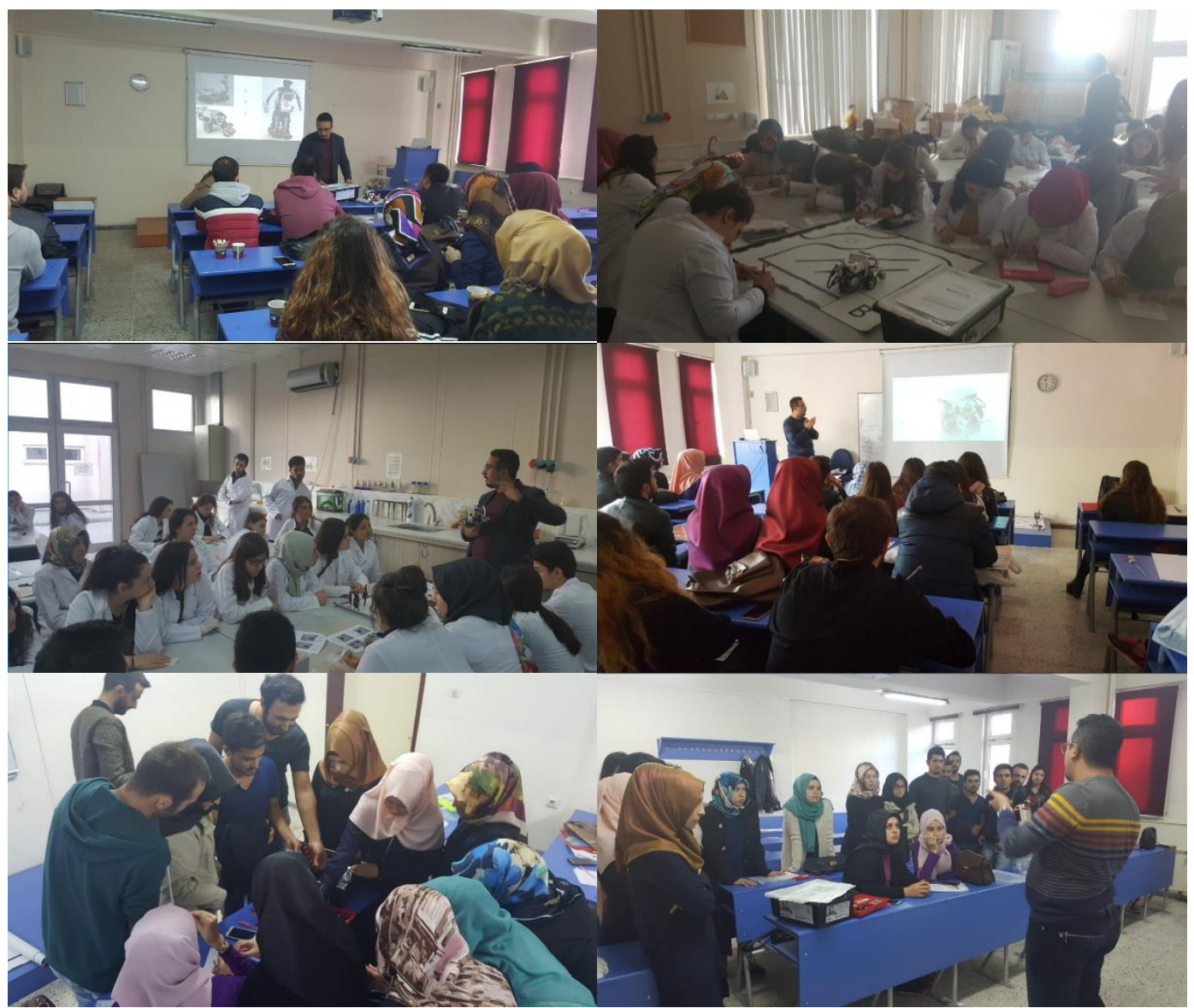

Picture 1. A Few Shots Captured during the Test Scale Application

As seen in Picture 1, LEGO Mindstorms EV3 set, a robot designed by the designers and a PowerPoint presentation were used while providing the aforementioned information. Following the demonstration which took around 15 minutes, preservice teachers were given some time to view the materials brought by the researchers. 
Thereafter, preservice teachers were asked to fill out the scale test form. All procedures performed in scope of the introduction of the LEGO Robotic instructional practices were repeated in all of the classrooms from which data were collected. Demonstration of the LEGO Robotic instructional practices and data collection process were completed within a period of two weeks.

\section{Data Analysis}

Correlation - based analysis (r) method was used in the item analysis studies. Pearson correlation coefficient was calculated for item- total test correlations. Additionally, following the exploratory factor analysis (EFA), confirmatory factor analysis (CFA) was performed for the test of the model introduced under the study. Principal components analysis was employed as a factor extraction method in the EFA. The software packages SPSS 22.0 and AMOS 23.0 were used in the analyses. Kaiser - Meyer - Olkin (KMO) test and Bartlett's test of sphericity were applied to examine conformity of the data with the EFA. The KMO coefficient was calculated as .945 and Bartlett's test of sphericity as $\mathrm{p}<.05$, which were found significant. The KMO value was higher than .70 and Bartlett's test of sphericity value was significant, which both evidenced that the data were eligible for performing an EFA (Bryman and Cramer, 1999).

H0 hypothesis was rejected in line with the KMO value and Bartlett's test of sphericity value. Thus, it was agreed that the size of sample group was adequate for acceptance scale of the LEGO robotic instructional practices to be subject to factor analysis. According to Büyüköztürk (2002), factor values below .30 indicate a relation at a low level. Therefore, only the items with a factor load over .30 were processed in the factor analysis. Items with a difference less than .10 between load values of two factors were omitted from the scale. Reliability of the scale and its components was estimated by using Cronbach's Alpha internal consistency coefficient. The model determined according to the results of EFA was tested via CFA, and chi-square $\left(\chi^{2}\right), \chi^{2} / \mathrm{sd}$, RMSEA, RMR, GFI, IFI, NNFI, NFI and AGFI goodness of fit indices for the model were examined.

\section{Findings}

Item- total test correlations of the scale items and factor structure of the scale are given in Table 1.

Tablo 1. LEGO Robotik Öğretim Uygulamalarının Kabulü Ölçeğinin Güvenirlik, Madde Toplam Test Korelasyonu ve Faktör Analizi Sonuçları

\begin{tabular}{cccc}
\hline $\begin{array}{c}\text { Item } \\
\text { No }\end{array}$ & $\begin{array}{c}\text { Item Total } \\
\text { Test Correlation }\end{array}$ & $\mathbf{1}$ & $\mathbf{2}$ Factor Loads \\
\hline M1 &, 740 &, 719 & $\mathbf{3}$ \\
M2 &, 813 &, 814 & \\
M3 &, 819 &, 813 & \\
M4 &, 796 &, 794 & \\
M5 &, 814 &, 802 & \\
M6 &, 743 &, 746 & \\
M7 &, 770 &, 747 &, 503 \\
M8 &, 784 &, 770 & \\
M9 &, 715 &, 721 & \\
M10 &, 642 &, 615 &, 522 \\
M11 &, 734 &, 752 &, 638 \\
M12 &, 739 &, 721 & \\
M13 &, 654 &, 624 & \\
M14 &, 611 &, 573 & \\
M15 &, 787 &, 784 & \\
M16 &, 721 &, 815 & \\
M17 &, 756 &, 829 & \\
M18 &, 771 &, 417 & \\
M19 &, 394 &, 775 & \\
M20 &, 725 &, 810 & \\
\hline
\end{tabular}




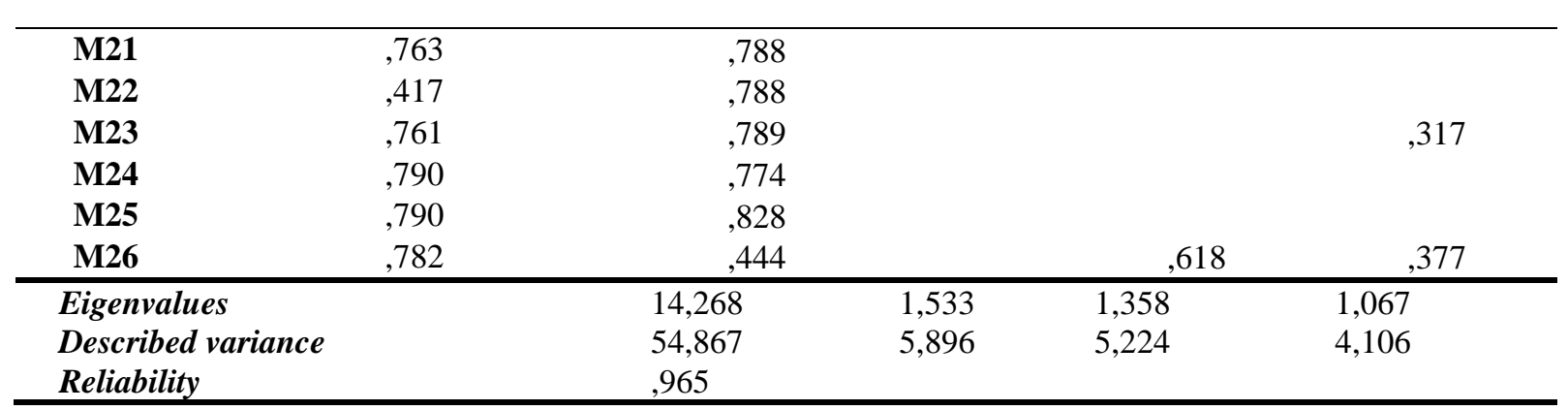

When Table 1 is examined, it is seen that the internal consistency coefficient of the scale test form is .965 . When the eigenvalue statistics of the scale are examined, it is seen that there are 4 factors with an eigenvalue over 1. The 1 st factor with an eigenvalue of 14,268 explains $54,867 \%$ of the variance while the 2nd factor with an eigenvalue of 1,533 explains 5,896\% of the variance. When eigenvalues and factor loads are examined together for unrotated results, it can be said that the scale has a one- dimensional structure due to the difference between eigenvalues of the 1 st and the 2 nd factors. (1) The scale test form has a high internal consistency coefficient (.965), (2) the variance ratio which the 1st factor alone explains is high, and (3) the eigenvalue of the 1st factor is about 10 times higher than that of the 2nd factor, which are the indicators of the fact that the scale is a one-factor scale. Varimax rotation method was used to provide a clearer description of the factor load distribution.

Results of the EFA analysis based on Varimax rotation method revealed that the scale has a structure with consists of a single factor and three components. Item - total test correlations, factor structure and Cronbach's alpha coefficient of reliability for the scale are given in Table 2.

Table 2. Factor Load Distribution of the Acceptance Scale of LEGO Robotic Instructional Practices According to Varimax Rotation Method

\begin{tabular}{|c|c|c|c|c|c|}
\hline \multirow[t]{2}{*}{ Item No } & \multirow{2}{*}{$\begin{array}{c}\text { Item Total } \\
\text { Test Correlation }\end{array}$} & \multicolumn{4}{|c|}{ Factor Loads } \\
\hline & & 1 & 2 & 3 & 4 \\
\hline M2 & .808 & .811 & & & \\
\hline M3 & .003 & .816 & & & \\
\hline M4 & .786 & .780 & & & \\
\hline M5 & .797 & .690 & & & \\
\hline M21 & .826 & & .597 & & \\
\hline M23 & .802 & & .630 & & \\
\hline M24 & .816 & & .745 & & \\
\hline M25 & .815 & & .794 & & \\
\hline M26 & .801 & & .804 & & \\
\hline M10 & .624 & & & .822 & \\
\hline M11 & .762 & & & .627 & \\
\hline M12 & .728 & & & .660 & \\
\hline M13 & .630 & & & .730 & \\
\hline M16 & .773 & & & & .813 \\
\hline M17 & .817 & & & & .794 \\
\hline M18 & .837 & & & & .650 \\
\hline \multicolumn{2}{|c|}{ Eigenvalues } & 9.718 & 1.142 & .950 & .776 \\
\hline \multicolumn{2}{|c|}{ Described variance } & 60.738 & 7.138 & 5.938 & 4.851 \\
\hline \multicolumn{2}{|c|}{ Reliability } & .924 & .929 & .834 & .915 \\
\hline
\end{tabular}

When Table 2 is examined, it is seen that item total test correlations are high. The four components explain $78.665 \%$ of the total variance. The first factor alone explains $60.738 \%$ of the variance and the Cronbach Alpha coefficient estimated for the entire scale was found .956 , which are indicators of the fact that the items have a homogeneous structure. Furthermore, when the eigenvalue statistical values are examined, it is seen that the $1 \mathrm{st}$ factor has an eigenvalue of 9,718 and the 2nd factor is about eight times higher than its eigenvalue, which both indicate that the scale has a one-factor and four-component structure. 
The Cronbach Alpha reliability coefficients for the components of the scale were found as .924; .929;.834 and .915, respectively. The Cronbach Alpha coefficient calculated for the entire scale was found as .956. If the Cronbach Alpha value is .70 and higher, it is accepted that the scale tested is reliable (Sipahi et al., 2010). In this context, the reliability values obtained in respect of the components and the entire scale manifest that the scale is a reliable data collection tool to determine to what extent LEGO robotics instructional practices are accepted. The Pearson Product-Moment Correlation Coefficients were calculated as the evidence of the validity of the scale; correlations between each of the components of the scale as well as between the components and the total score of scale are shown in Table 3.

Table 3. Component and Total Score Correlations

\begin{tabular}{llllll}
\hline & 1. Component & 2. Component & 3. Component & $\begin{array}{l}\text { 4. } \\
\text { Component }\end{array}$ & $\begin{array}{l}\text { Total } \\
\text { Points }\end{array}$ \\
\hline 1. Component & $1 * *$ & $.735^{* *}$ & $.642^{* *}$ & $.731^{* *}$ & $.885^{* *}$ \\
2. Component & $.735^{* *}$ & $1 * *$ & $.686^{* *}$ & $.762^{* *}$ & $.921^{* *}$ \\
3. Component & $.642^{* *}$ & $.686^{* *}$ & $1 * *$ & $.646^{* *}$ & $.837^{* *}$ \\
4. Component & $.731^{* *}$ & $.762^{* *}$ & $.646^{* *}$ & $1 * *$ & $.875^{* *}$ \\
\hline
\end{tabular}

As seen in Table 3, there is a meaningful positive correlation between each of the components as well as between the components and the total score. These findings reveal that the scale has a one-factor and fourcomponent structure. The final version of the scale consists of 16 items. When the distribution of the items in the scale by component is examined, it is seen that the first component consists of items 2, 3, 4 and 5. This component is referred to as the perceived usefulness (A.F.). This is due to the fact that the items in this component reflect the benefits provided by the use of the LEGO robotic instructional practices in the learning - teaching process. The items in this component are as follows:

Item 2. Using LEGO Mindstorms increases my productivity in classes.

Item 3. Using LEGO Mindstorms improves my performance in classes.

Item 4. Using LEGO Mindstorms increases my efficiency in classes.

Item 5. I think that using LEGO Mindstorms is useful for activities related to my school life.

The second component contains the items 21,23, 24, 25 and 26. This component is referred to as the intention towards use (A.K.K.). The items in this component show the intention towards the use of the LEGO robotic instructional practices in the learning - teaching process. The items in this component are as follows:

Item 21. I want to do LEGO Mindstorms practices in my classes.

Item 23. I would like to do LEGO Mindstorms practices in my future classes.

Item 24. I will encourage my colleagues to do LEGO Mindstorms practices.

Item 25. I will include LEGO Mindstorms practices in my education and teaching career.

Item 26. I will use LEGO Mindstorms practices in solution of problems.

The third component consists of the items 10,11, 12 and 13. This component is referred to as the perceived ease of use (K.T.). The items in this component emphasize that the LEGO robotic instructional practices will require little effort for their use in the learning - teaching process. The items in this component are as follows:

Item 10. I find it easy to learn LEGO Mindstorms applications.

Item 11. I easily teach lessons with LEGO Mindstorms practices.

Item 12. The steps that I have to take to solve any problem in LEGO Mindstorms practice are clear and comprehensible.

Item 13. I think I will easily master LEGO Mindstorms practices.

The fourth component consists of the items 16,17 and 18. This component is referred to as the attitude towards use (K.N.). The items in this component include expressions reflecting the attitude towards the use of the LEGO robotic instructional practices in the learning - teaching process. The items in this component are as follows: 
Item 16. It would be fun to do LEGO Mindstorms practices in my classes.

Item 17. I would enjoy doing LEGO Mindstorms practices in my classes.

Item 18. It would make me happy to do LEGO Mindstorms practices in my classes.

The model determined according to results of the EFA were tested via CFA; following the analyses, goodness of fit indices for the model were examined. Chi-square $\left(\chi^{2}\right), \chi 2 /$ sd, RMSEA, RMR, GFI and AGFI statistics are among the most commonly used statistics estimated with regard to CFA and model data fit (Duyan and Gelbal, 2008). It was indicated that the $\chi 2 / \mathrm{df}$ ratio smaller than 5 is considered as an indicator of acceptable fit model (Kline, 2005), so it was suggested that the $\chi 2 / \mathrm{df}$ ratio should be below 5 (Hooper, Coughlan and Mullen, 2008). Moreover, a GFI value over 0.85, an AGFI value over 0.80 and RMR and RMSEA values below 0.10 are considered as the acceptable lower limits for model data fit (Anderson and Gerbing, 1984; Cole, 1987, Meydan and Şeşen, 2011). As for the statistics calculated with regard to CFA and model data fit, RMSEA was calculated as (.086), NFI and NNFI as (.93), PNFI as (.76), CFI as (.94), GFI as (.88), AGFI as (.84), chi-square/degree of freedom as (3.65). Considering the goodness of fit indices obtained in relation to the model, it can be said that the model gives a good fit to observed structure. The path diagram for the 'acceptance of the use of LEGO robotic instructional practices in the learning - teaching process' model is presented in Figure 1.

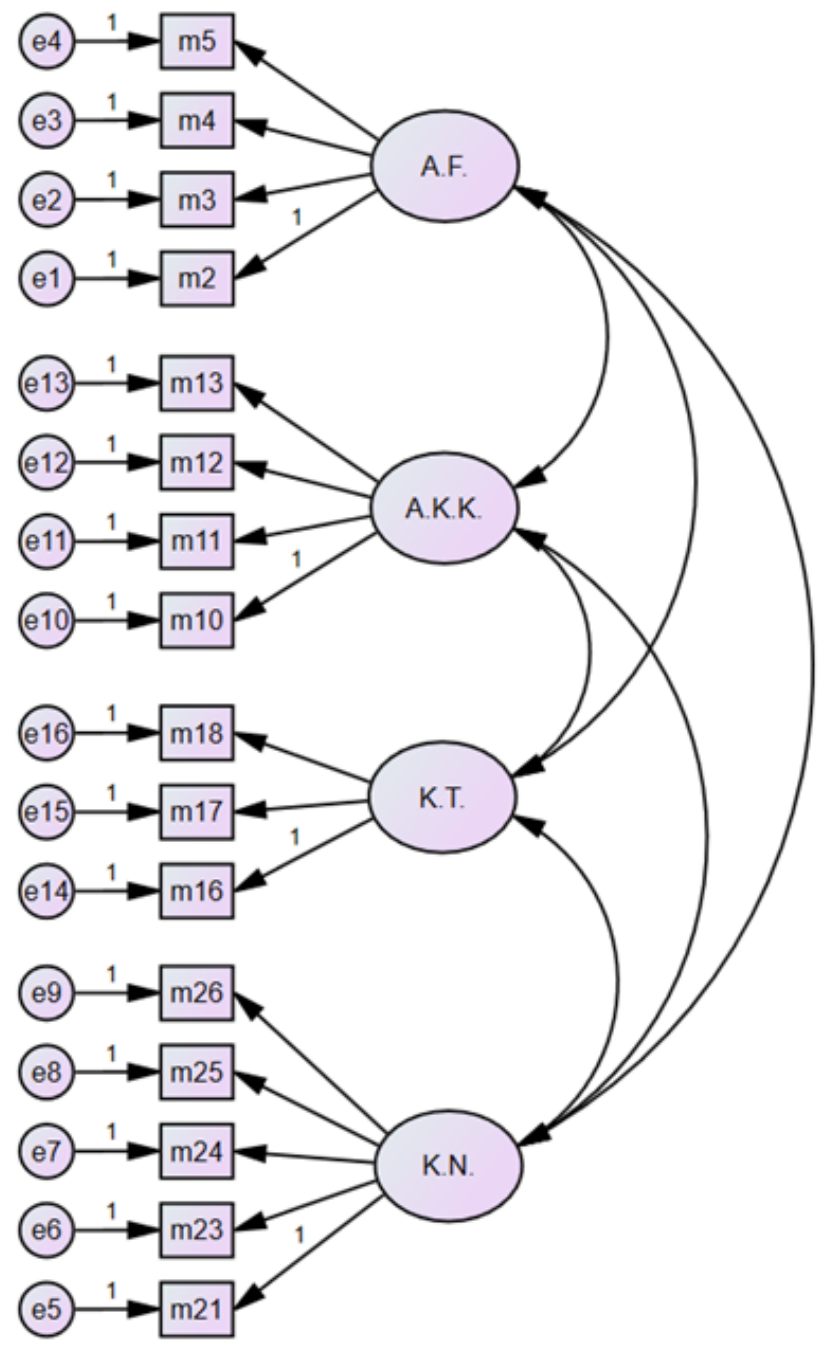

Figure 1. Path diagram for the 'acceptance of the use of LEGO robotic instructional practices' 


\section{Discussion, Conclusion and Suggestions}

A scale was developed under the study with a view to identify preservice teachers' levels of acceptance of LEGO robotic instructional practices and to test validity and reliability. In frame of the scale development study, data were collected from preservice teachers studying in the 3rd and 4th years of their undergraduate education at the Faculty of Education, Bartın University in the academic year 2016 - 2017. Prior to the data collection process, a literature review was conducted on the technology acceptance model and LEGO robotic instructional practices, and items were written for the scale test form. Expert opinion was received from the experts at Departments of Computer and Instructional Technologies, Educational Sciences and Turkish Education with regard to the items of scale in the test form. In this frame, experts were asked to evaluate the items of the scale in terms of criteria such as the extent to which the items comprise the variance to be assessed, conformity of the items with the factor or factors to be assessed, expression of the items in a comprehensible and clear manner, conformity of the items with the study group, etc..; the final version of the scale test form was created after feedbacks received and revisions made. Before the process in which the scale form was applied to the study group, the entire study group was given a demonstration, by video presentations, on the theme of how LEGO Mindstorms EV3 set and LEGO Mindstorms EV3 set can be used in learning - teaching processes, and questions directed by the preservice teachers on the mentioned topics were answered.

As a result of the EFA studies, it is seen that the variance value explained is $78.665 \%$. The explanatory variance value obtained (78.665\%) was considered adequate in making a decision as to the factor structure of the scale. On basis of the fact that the first factor alone explains $60.738 \%$ of the variance, the scale exhibits a one-factor structure (one factor - four components). Furthermore, when the eigenvalue statistical values are examined, it is seen that the first factor has an eigenvalue of 9,718 and the second factor is about eight times higher than its eigenvalue, which both indicate that the scale has a one-factor and four-component structure. The Cronbach Alpha reliability coefficient calculated for the entire scale was found as .956; while the Cronbach Alpha reliability coefficients for the components of the scale were found as $.924 ; .929 ; .834$ and .915 , respectively. In this context, the reliability values obtained in respect of the components and the entire scale manifest that the scale is a reliable data collection tool to determine to what extent LEGO robotics instructional practices are accepted. When the Pearson ProductMoment Correlation Coefficients are calculated and correlations between components of the scale as well as between with the total score of scale are examined, it is obviously seen that components represent a meaningful correlation between each other and with the total score of the scale.

Confirmatory factor analysis was carried out to test the model identified upon exploratory factor analysis under the study. As for the statistics calculated with regard to Confirmatory Factor Analysis and model data fit, RMSEA was calculated as (.086), NFI and NNFI as (.93), PNFI as (.76), CFI as (.94), GFI as (.88), AGFI as (.84), chisquare/degree of freedom as (3.65). Considering the goodness of fit indices obtained in relation to the model, it can be said that the model gives a good fit to observed structure.

As a result of exploratory and confirmatory factor analysis activities, it was concluded that the acceptance scale of the LEGO robotic instructional practices represents a one-factor and four-component structure consisting of 16 items. By having regard to the components of technology acceptance model, components of the scale were identified as follows: perceived usefulness, perceived ease of use, attitude and intention towards use.

In today's educational environment in which technology- supported instructional practices are an integral part of classrooms, LEGO robotic instructional practices will inevitably lead the learning - teaching process. As the LEGO robotic instructional practices can be functionally used at any stage of education from primary school to college level and in any discipline, it is expected that these practices will be adopted by teachers and the quality of education is enhanced by teachers using these practices. A data collection tool is required to assess levels of acceptance by teachers or preservice teachers of these practices so that reliable information will be acquired in respect of the realization status of this expectation. Thus, the 'acceptance of LEGO robotic instructional practices' scale will enable easier collection of data on to what extent teachers or preservice teachers adopt and use LEGO robotic practices in their teaching. Furthermore, the scale developed by the researchers can be functionally used at faculties of education in order to acquire information about to what extent preservice teachers subject to an instructional process supported by LEGO robotic instructional practices adopt such practices and use them in their teaching when they are qualified as teachers, and to carry out scientific studies on this subject. Moreover, structural models produced in scope of factors which are considered to have a direct or indirect effect on levels of acceptance by teachers or preservice teachers of the LEGO robotic instructional practices can be tested. Additionally, this 
scale may be adapted to learners of various educational levels, who will be ensured to design robots by using the LEGO robotic instructional practices and to use the robots they designed for learning purposes.

\section{Acknowledgments}

This work was supported by the Bartın University Scientific Research Projects Committee (Project number: 2016-SOS-A-014). 


\section{LEGO Robotik Öğretim Uygulamalarının Kabulü Ölçeğinin Geliştirilmesi: Geçerlik ve Güvenirlik Çalışmaları}

\section{Giriş}

Bireyin kişisel gelişimine katkı sağlama ve sosyal bir varlık olarak bulunduğu toplumda belli bir statü kazanmasına yardımcı olma amacı taşıyan eğitim, toplumsal yaşamı düzenleyen diğer sistemlerde olduğu gibi değişen koşullara göre kendini sürekli olarak yenilemek zorundadır. Bu yenileşme, kullanılan materyallerden ölçme değerlendirme yöntemlerine kadar birçok boyutta da geleneksel anlayışın yerini 21. yüzyılın gerektirdiği modern eğitim anlayışlarının benimsenmesi sonucunu doğurmuştur. Bu kapsamda geliştirilen yeni öğretim programlarında, öğrenenlerin daha bilgili ve üretken olmalarının sağlanması için bu programların esnek, ilgi/dikkat çekici ve yaratıcı olmaları gerekliliği ortaya konulmuştur (Erbaş ve Demirer, 2015). Ayrıca günümüz öğrenenlerinin birer dijital yerli olması (Prensky, 2001) ve değişen öğrenen özellikleri, eğitim-öğretim süreçlerinde önemli değişimleri zorunlu hale getirmiştir (Pala ve Erdem, 2015). Dolayısılla teknolojinin eğitimle bütünleștirildiği uygulamalar yeni öğretim programlarıyla birlikte öne çımaya başlamıștır. Özellikle yapılandırmacı ve öğrenci merkezli öğrenme, günümüz eğitim ortamlarında dikkate alınan yaklaşımlar haline geldikten sonra eğitimde teknoloji kullanımları bu konulara odaklanmıştır (Uğur Erdoğmuş ve Çağıltay, 2013). Bununla birlikte teknoloji destekli öğretim çalışmaları öğretim teorilerini uygulama hususunda büyük firsatlar sunmakta ve teknolojideki gelişmeler yapılandırmacı yaklaşımla öğrenmeyi daha mümkün kılmaktadır (Karagiorgi ve Symeou, 2005). Günümüzde bireyin somut materyallerle ders içeriğini zihninde yapılandırdığı, yaparak yaşayarak öğrenmenin önemsendiği ve öğrenen özerkliğinin desteklendiğgi uygulamalar; öğrenme öğretme etkinlikleri sonucunda istendik öğrenme çıtılarının elde edilmesine katkı sağlayacak unsurlar olarak görülmektedir. Eğitim teknolojileri bu bağlamda kullanılacak uygulamalardan biri olmakta ve günümüzde birçok farklı türde teknoloji kullanılarak eğitim-öğretim sürecinin desteklenmediği bir eğitim düşüncesi neredeyse imkansız olarak görülmektedir (Spector, 2016).

Eğitim teknolojisi, öğretim anlayışı ile teknolojinin entegrasyonunu içermektedir (Koehler, Mishra, Kereluik, Shin ve Graham, 2014). Bir başka deyişle eğitim teknolojisi, eğitim öğretim süreçlerini en iyi bir şekilde planlamak, gerçekleştirmek ve değerlendirme yapmak amacıyla eğitim öğretim süreçlerine sistematik bir yaklaşımdır (Alkan, 2011). Ayrıca, eğitim teknolojisi öğrenmeyi, öğretimi veya performansı geliştirmek amacı için disiplinli olarak bilginin uygulanmasını içermektedir (Spector, 2016). Günümüzde farklı özelliklerde birçok eğitim teknolojisi kullanılmaktadır. Arttırılmış gerçeklik, sanal gerçeklik, uyarlanabilir öğrenme ortamları, çevrimiçi öğrenme, giyilebilir teknolojiler, mobil öğrenme, yeni nesil öğrenme yönetim sistemleri, doğal kullanıc1 arayüzleri, internet araçları, ters yüz edilmiş sınıf modeli (flipped classroom) günümüzde yaygın olarak kullanılan ve gelişmekte olan eğitim teknolojilerinden bazılarıdır (NMC, 2017; Johnson, ve diğerleri, 2016; Adams Becker, ve diğerleri, 2016; Johnson, Adams Becker, Estrada ve Freeman, 2015). Bu teknolojilerin yanı sira eğitsel robotik uygulamaları eğitim teknolojileri alanındaki gelişmekte olan önemli teknolojiler arasında yer almaktadır (Johnson ve diğerleri, 2016; Benitti, 2012).

Eğitsel robotik uygulamaları öğretim amaçlı robot kullanımına dayanan bir öğretimsel stratejidir (Catlin, 2012). Eğitsel robotik uygulamalar için tasarlanan çalışma materyalleri, genellikle öğrenenlerin öğrenmelerine destek olacak şekilde hazırlanmaktadır (Ospennikova, Ershov ve Iljin, 2015). Eğitsel robotik uygulamaları öğrencilerin ilgisini çekmekte (Prensky, 2010), motivasyonlarını artırmaktadır (Ortiz, 2015). Bununla birlikte eğitsel robotik uygulamalar yaratıcı ortamlar meydana getirmekte (Catlin, 2012), bilgisayarca düşünme becerilerinin gelişmesini sağlamaktadır (Kazimoglu, Kiernan, Bacon ve Mackinnon, 2012). LEGO Mindstorms robotik uygulamaları, öğrenme öğretme sürecinde yaygın olarak kullanılan, günümüz popüler eğitsel robotik uygulamaları arasında yer almaktadır.

LEGO ürünleri çeşitli renklerdeki yapı parçalarından oluşan ve bu parçaların üzerlerindeki girintiler/çıkınlar aracılığıyla birbirine bağlanmasıyla ortaya bir yapının meydana getirildiği bir oyuncak çeşididir. LEGO ürünleri öğrencilerin derse ilgisini arttıran ve eğlenirken öğrenmelerini sağlayan etkili parçalardır (Sungur, 2013). Bu parçalar ile birlikte ışık, ultrasonik, ses, dokunma sensörlerinin, servo motorların ve programlanabilir bir parçanın (EV3 Brick gibi) yer aldığı ürünler LEGO Mindstorms ürünleri olarak adlandırılmaktadır. LEGO Mindstorms ürünleri ile oluşturulan yapının önceden belirlenmiş görevleri yerine getirmesi amacıyla programlanması (genellikle LOGO programlama dili ile) ile oluşan ürünler ise eğitsel LEGO robotik öğretim uygulamaları (LEGO uygulamaları) olarak ifade edilmektedir. Alan yazın incelendiğinde dünya genelinde LEGO uygulamalarının öğrenme öğretme sürecinde kullanılmasına yönelik çok sayıda çalışmaya rastlanılmaktadır. Bu çalışmalar incelendiğinde LEGO uygulamalarının öğrenme öğretme sürecine olan katkıları şu şekildedir:

- Öğrenen aktif bir şekilde görev almaktadır (Kazez ve Genç, 2016). 
- Öğrenenlerin öğrenmeye ve derse yönelik motivasyonunu olumlu yönde etkilemektedir (Ortiz, 2015; Aufderheide, Krybus ve Witkowski, 2012, Murillo, Masteo, Castellanos ve Montano, 2011).

- Öğrenenlerin yaparak, deneyerek, tasarlayarak öğrenmelerine yardımcı olur (Somyürek, 2015).

- Öğrenenlerin derse yönelik olumlu tutum geliştirmesine katkı sağlar (Özdoğru, 2013).

- Öğrenenlerin problem çözme becerilerinin gelişmesinde etkili olur (Castledine ve Chalmers, 2011)

- Grup çalışması yapılmasına olanak vermekte ve öğrenenlerin iş birlikli öğrenme becerilerinin gelişmesinde etkili olmaktadır (Aufderheide, Krybus ve Witkowski, 2012).

- Öğrenenlerin derse yönelik tutumlarının gelişmesine katkı sağlar (Beisser, 2005).

- Öğrenenlerin akademik başarılarını olumlu yönde etkilemektedir (Strawhacker ve Bers 2015; Murillo, ve diğerleri, 2011)

- Öğrenenlerin bilimsel süreç becerilerinin gelişmesine katkı sağlamaktadır (Çayır, 2010).

LEGO uygulamaları öğrenme öğretme sürecinde yaygın bir şekilde kullanılmaktadır. Bu süreçte hedeflere ulaşılmasında öğretici ve öğrenenlerin robotik uygulamalara yönelik ilgili ve istekli olması önem arz etmektedir. Özellikle derslerde kullanılmak istenen robotik uygulamalar için gerekli planlama, tasarlama ve uygulama sürecinde önemli bir role sahip olan öğreticilerin LEGO robotik öğretim uygulamalarını kullanmaya yönelik istekli/niyetli olması, yapılacak çalışmaların etkililiğinin sağlanması ve LEGO robotik öğretim uygulamalarının yapılması büyük öneme sahiptir. Yapılan çalışmalarda yer alan öğreticilerin LEGO robotik öğretim uygulamalarındaki rolleri incelendiğinde bu durumun desteklendiği görülmektedir (Mcknight, 2015; Ortiz, 2015; Strawhacker ve Bers 2015). Dolayısıyla robotik öğretim uygulamalarında öğretici rolüne sahip olması muhtemel olan öğretmen adaylarının LEGO robotik öğretim uygulamalarını kullanmaya yönelik istekli/niyetli olup olmama durumlarının incelenmesi gerekliliği ortaya çıkmaktadır. Bu durumun incelenmesi hususunda teknoloji kabul modeli öne çıkmaktadır.

Teknoloji kabul modeli (Technology Acceptance Model, TKM), teknolojileri yönelik olarak çok yaygın bir şekilde kullanılan bir modeldir (Hsia, 2016). TKM, bireylerin ilgili teknolojiyi kabul etme durumlarını algılanan kullanım kolaylığı ve algılanan fayda yapıları temelinde belirlemeyi amaçlamakta (Teo, 2010; Davis, 1989), algılanan kullanım kolaylığı ve algılanan fayda TKM'nin birincil belirleyicileri olarak belirtilmektedir (Khee, Wei ve Jamaluddin, 2014; Davis, 1989). Algılanan fayda, bireyin ilgili teknolojiyi kullandıktan sonra ilgili konu çerçevesinde kendi iş/çalışma/beceri/vb. performansının artacağı inancı; algılanan kullanım kolaylığı ise, bireyin ilgili teknolojiyi çok az çaba harcayarak kullanabileceği inancı olarak açılanmaktadır (Hsia, 2016). Modelde, bireyin ilgili teknolojiyi kullanmaya yönelik tutumunu belirlemede, o teknoloji ile ilgili bireydeki algılanan kullanım kolaylığı ve algılanan faydanın etkili olduğu; bireyin teknolojiyi kullanmaya yönelik niyetini belirlemede de bireyin teknolojiyi kullanmaya yönelik tutumunun doğrudan etkili olduğu, algılanan kullanım kolaylığı ve algılanan faydanın dolaylı olarak etkili olduğu belirtilmektedir (Dastjerdi, 2016). İlgili teknolojiyi kullanmaya yönelik niyetine bağlı olarak bireyde teknolojiyi kullanma davranışı gerçekleşmektedir (Davis, 1993).

Alanyazında robotik uygulamalar ile TKM'nin incelendiği Türkiye'de gerçekleştirilmiş çalışmaya rastlanılmamış, dünya genelinde gerçekleştirilmiş çok az sayıda çalışmaya rastlanılmıştır. Bu çalışmalardan bazıları LEGO robotik öğretim uygulamaları ile ilgili, bazıları ise farklı alanlardaki robotik uygulamalar ile ilgili olduğu görülmüştür. Chesney (2006) yaptığı çalışmada eğlence odaklı yazılım (EOY) sistemlerin kabulünü araştırmışlardır. Bu bağlamda EOY sistemlerinin kabulü ile ilgili geliştirilmiş bir ölçeği LEGO Mindstorms ürünlerini kullanan 68 kullanıcı uygulamışlardır. Çalışmada EOY sistemleri için algılanan faydanın algılanan kullanım kolaylığına karar vermede baskın öğe olduğu; algılanan kullanım kolaylığının kullanmaya yönelik niyet üzerinde doğrudan bir etkisi olmadığı görülmüștür. Bununla birlikte alternatif EOY sistemlerinin incelenmesi ve kullanıcıların alternatif EOY sistemlerini kullanmaya yönelik niyetlerinin daha fazla olabileceği belirtilmiștir. Shih ve diğerleri (2011) yaptıkları çalışmada öğrencilerin LEGO Mindstorms NXT'ye yönelik kabul etme durumlarını TKM'ye göre tahmin etmek, açıklamak ve geliştirmek için değerlendirme aracı geliştirmek amaçlanmıştır. Daha önce LEGO Mindstorms NXT setini kullanan 69 ilköğretim öğrencisi araştırmanın örneklemini oluşturmuştur. LEGO Mindstorms NXT setinin TKM'ye göre kabulü ölçeği ve LEGO Mindstorms NXT setine yönelik özyeterli algısı ölçeği vasıtasıyla veri toplama işlemi gerçekleştirilmiştir. Araştırmanın sonucunda öğrencilerin LEGO Mindstorms NXT setini kabul durumlarının TKM'ye göre uygun olduğu belirtilmiştir. Shih, Chen, Chen ve Hsin (2012) yaptıkları çalışmada doğal felaketleri engelleme programı için LEGO Mindstorms NXT kullanımının 
etkililiği incelenmiştir. Bu doğrultuda kullanıcıların LEGO ürünlerini kullanmaya yönelik niyetleri TKM ile incelenmiştir. İlköğretim düzeyinden üniversite düzeyine kadar olan ve daha önce LEGO Mindstorms NXT setini kullanan toplamda 172 kişi araştırmanın katılımcılarını oluşturmuştur. Araştırmacılar tarafından geliştirilen bir anket vasıtasıyla veri toplama işlemi gerçekleştirilmiştir. Araştırmanın sonucunda LEGO'nun belirlenen amaç doğrultusunda kullanımına ilişkin kabul durumlarının TKM'ye göre sağlandığı belirtilmiştir. Bunun yanı sıra algılanan kullanım kolaylığının istatistiksel olarak anlamlı olmadığı, algılanan fayda, kullanıma yönelik tutum ve kullanmaya yönelik niyet için yüksek düzeyde anlamlılık ortaya çıktığı ifade edilmiştir. Heerink, Krose, Evers ve Wielinga (2006) yaptıkları çalışmada ise iCat isimli bir robotik teknoloji kullanılmış, yaşlı kullanıcıların robotları kabul etme durumları ve robotlara yönelik tutumları ile birlikte çalışmada robotların yaşlı kullanıcıların sosyal becerilerine etkisi incelenmiştir. Yaşı bakım enstitülerinde yaşamını sürdüren 28 yaşlı katılımcı ile çalışma gerçekleştirilmiştir. Gözlem, görüşme ve anket yoluyla veri toplama işlemi gerçekleştirilmiştir. Çalışmanın sonucunda TKM'nin sosyal becerilere yüksek düzeyde bir etkisinin olmadığı, yaşlı kullanıcıların robotlara yönelik tutumlarının iyi düzeyde olduğu belirtilmiştir.

LEGO robotik öğretim uygulamalarını kabul etme durumlarına yönelik alanyazın incelendiğinde gerçekleştirilen çalışmaların LEGO Mindstorms ürünlerinin eski versiyonlarına (RCX ve NXT) ait olduğu, çalışmalarda belirli bir konuya yönelik LEGO ürünlerinin kabul edilme durumlarının incelendiği görülmektedir. Yapılan alanyazın taraması sonucunda LEGO Mindstorms EV3 ürünlerinin öğretim uygulamalarında kullanıldığı, öğretmen adaylarının LEGO robotik öğretim uygulamalarını kabul etme durumlarının incelendiği bir çalışmaya rastlanılamamıştır ve bu konularda araştırmalara gereksinim vardır.. Dolayısıyla araştırmada öğretmen adaylarının LEGO Robotik öğretim uygulamalarını kabul etme durumlarını belirlemek için "LEGO Robotik Öğretim Uygulamalarının Kabulü” ölçeğinin geliştirilmesi amaçlanmıştır. Bu amaç doğrultusunda geliştirilen ölçeğin alanyazına katkı sağlayacağına ve gelecekte yapılacak çalışmalar için kullanılabilir bir ölçme aracı geliştirildiğine inanılmaktadır. Ayrıca Milli Eğitim Bakanlığı (MEB) tarafından ortaokul düzeyinde Bilgisayar Bilimi dersi kapsamında robotik öğretim uygulamalarının yer aldığı bir öğretim programı hazırlanmıştır (MEB, 2016). Bilgisayar Bilimi dersi öğretim programının genel amaçları arasında öğrencilerin "robot programlama konusunda temel bilgilerle donanmaları", "programlama konusunda teknik birikim oluşturmaları" ve "algoritma tasarımına ilişkin anlayış geliştirerek sözel ve görsel olarak ifade etmeleri” yer almaktadır (MEB, 2016). Ayrıca ders kapsamında robot programlama ünitesinin yer aldığ 1 ve robot kitlerinin kullanılabileceği belirtilmektedir (MEB, 2016). Bu bağlamda geleceğin öğretmenleri olan öğretmen adaylarının eğitsel robotik uygulamalarından biri olan LEGO uygulamalarını benimseme durumlarının incelenmesinin önem arz ettiğine inanılmaktadır. Bu bağlamda araştırma kapsamında geliştirilen ölçeğin alana katkı sağlayacağı düşünülmektedir.

\section{Yöntem}

Öğretmen adaylarının LEGO Robotik öğretim uygulamalarını kabul etme durumlarını belirlemek için "LEGO Robotik Öğretim Uygulamalarının Kabulü” ölçeğinin geliştirilmesi amaçlanmıştır. Bu amaç doğrultusunda alanyazına geçerli ve güvenilir bir ölçme aracı kazandırılması için ölçme aracı geliştirme çalışması yapılmıştır.

\section{Katılımcilar}

Ölçek geliştirme çalışması 2016-2017 öğretim yılında Bartın Üniversitesi Eğitim Fakültesi 3. ve 4. sınıflarında öğrenim gören 360 öğretmen adayıyla gerçekleştirilmiştir. Öğretmen adaylarının 180’i (\%50) Fen Bilgisi Öğretmenliği, 84’ü $(\% 23,4)$ Sinıf Öğretmenliği, 29’u (\%8) Matematik Öğretmenliği ve 67'si $(\% 18,6)$ Sosyal Bilgiler Öğretmenliği programlarında öğrenim görmektedirler. Örneklem büyüklüğünün gözlenen değişken sayısının en az beş katı olması açıklaması (Büyüköztürk, 2002; Child, 2006) doğrultusunda ölçek geliştirme çalışması için katılımcı sayısının faktör analizi tekniğinin kullanımı için yeterli olduğu sonucuna varılabilir.

\section{Veri Toplama Süreci ve Analizi}

\section{Ölçek Deneme Formunun Hazırlanması}

Teknoloji kabul modeline ve LEGO robotik öğretim uygulamalarına ilişkin alanyazın taramasının ardından oluşturulan ölçek deneme formunun maddelerine ilişkin Bilgisayar ve Öğretim Teknolojileri Bölümünde 5 uzmanının, Eğitim Bilimleri Bölümünde 3 uzmanın ve Türkçe Eğitimi Bölümünde 1 uzmanın görüşleri alınmıştır. Maddelerin ölçülmek istenen değişkeni kapsama durumları, maddelerin ölçülmek istenen faktör ya da faktörlere uygunlukları, maddelerin anlaşılır olması ve açık olarak ifade edilme durumu, maddelerin çalışma grubuna uygunluğu, vb. değişkenler bağlamında denemelik ölçek formu maddeleri uzmanlar tarafından incelenmiştir. 
Uzman görüşlerine dayanarak, bazı maddeler ölçek formundan çıkarılmış, bazıları ise uzman görüşleri doğrultusunda revize edilmiştir. Bu işlemin ardından tekrar aynı uzmanlardan görüş alınmış ve denemelik ölçek formuna son şekli verilmiştir. Deneme formunda 26 madde yer almaktadır ve deneme formu 5'li Likert tipi ölçek formunda tasarlanmış, ölçek kategorileri; "Kesinlikle Katılmıyorum (1)", "Katılmıyorum (2)”, "Kısmen Katılıyorum (3)", "Katılıyorum (4)" ve "Kesinlikle Katılıyorum (5)” olarak belirlenmiştir.

Denemelik ölçek formu 2016-2017 akademik yılı güz döneminde Bartın Üniversitesi Eğitim Fakültesinde öğrenim gören öğretmen adaylarına uygulanmıştır. Bu uygulama sürecinde LEGO robotik öğretim uygulamalarında kullanılmaya hazır halde olan 2 adet LEGO Mindstorms EV3 Education seti kullanılmıştır. Setin biri robot tasarımına hazır halde bulunurken diğer set ile araştırmacılar tarafından bir robot tasarımı yapılmıştır. Buna ek olarak araştırmacılar tarafından uygulama yapılan lisans programlarının öğretim planları dikkate alınarak birer örnek LEGO robotik öğretim uygulaması gösterilmiştir. Bunun yanı sıra genel olarak LEGO robotik öğretim uygulamaları ile ilgili araştırmacılar tarafından yapılan tasarımlar kullanılmıştır. Uygulama sürecinde öğretmen adaylarına LEGO Mindstorms EV3 seti ile ilgili tanıtım yapılmış, LEGO Mindstorms EV3 setinin öğrenme öğretme süreçlerinde nasıl kullanılabileceğine ilişkin araştırmacılar tarafından hazırlanan 5 dakikalık bir video öğretmen adaylarına izlettirilmiştir. Tanıtım ve video gösteriminin ardından LEGO seti kutusu ve tema sahası malzemeleri öğretmen adaylarına gösterilmiş ve robot tasarımı nasıl yapıldığına ilişkin kısa bilgiler verilmiştir (Resim 1).

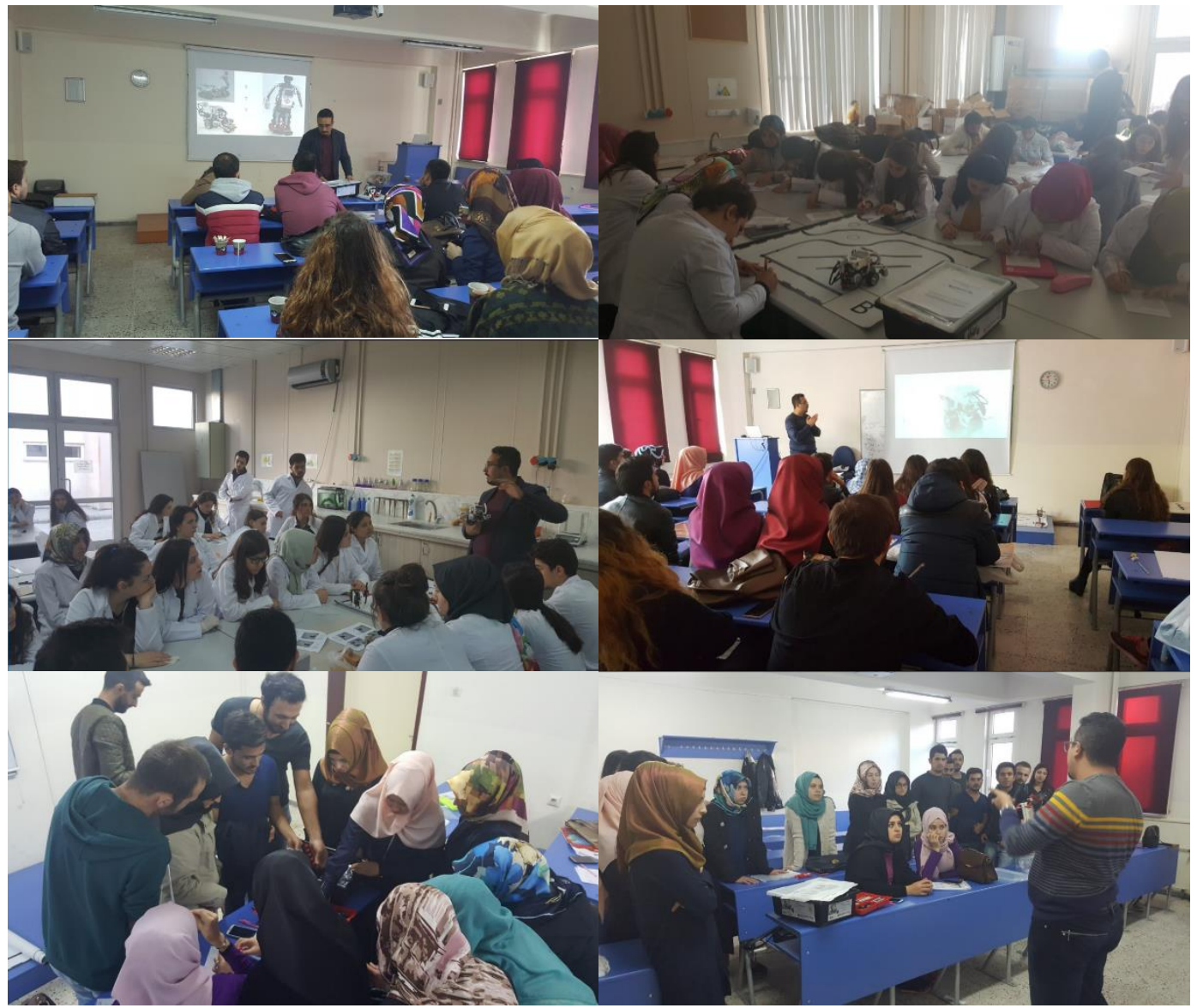

Resim 1. Denemelik Ölçek Uygulama Çalışması Sırasında Bazı Görüntüler

Resim 1'de görüldüğü gibi, bu bilgilerin verilmesi aşamasında LEGO Mindstorms EV3 seti, araştırmacılar tarafından tasarımı yapılmış bir robot ve PowerPoint sunumu kullanılmıştır. Ortalama 15 dakika süren tanıtımın ardından araştırmacılar tarafından getirilen malzemeleri incelemeleri için öğretmen adaylarına kısa bir süre tanınmıştır. Bu sürecin ardından öğretmen adaylarından denemelik ölçek formunu doldurmaları istenmiştir. LEGO Robotik öğretim uygulamalarının tanıtımı kapsamında yapılan tüm işlemler veri toplanan sınıfların tamamında 
tekrarlanmıştır. LEGO Robotik öğretim uygulamalarının tanıtımı ve veri toplama işlemi iki hafta sürecinde tamamlanmıştır.

\section{Verilerin Analizi}

Madde analizi çalışmalarında korelasyona dayalı analiz (r) yöntemi kullanılmıştır. Madde toplam test korelasyonları için Pearson korelasyon katsayısı hesaplanmıştır. Ayrıca araştırmada açımlayıcı faktör analizinden (AFA) sonra ortaya konulan modelin testi için doğrulayıcı faktör analizi (DFA) yapılmıştır. AFA'da faktör çıkartma tekniği olan temel bileşenler analizi kullanılmıştır. Analizlerde SPSS 22.0 ve AMOS 23.0 paket programları kullanılmıştır. Verilerin AFA'ya uygunluğunu incelemek için Kaiser-Meyer-Olkin (KMO) testi ve Bartlett' in küresellik testi uygulanmıştır. Hesaplanan KMO katsayısı .945 ve Bartlett'in Küresellik Testi değeri p <.05 düzeyinde önemli bulunmuştur. KMO değerinin .70’ten büyük olması ve Barlett'in Küresellik Testi değerinin önemli olması verilerin AFA yapmak için uygun olduğunu göstermiştir (Bryman ve Cramer, 1999).

KMO ve Bartlett'in Küresellik Testinin değerleri doğrultusunda H0 hipotezi reddedilmiştir. Dolayısıyla örneklem büyüklüğünün LEGO robotik öğretim uygulamalarının kabulü ölçeğinin faktör analizine tabii tutulması için yeterli olduğu kabul edilmiştir. Büyüköztürk’e (2002) göre .30’un altındaki faktör yük değerleri düşük düzeyde ilişki olduğunu göstermektedir. Dolayısıyla faktör analizinde sadece faktör yükü .30'un üzerinde olan maddeler üzerinde işlem yapılmıştır. Ölçekte iki faktördeki yük değeri fark1 .10'dan küçük olan maddeler ölçekten çıkarılmıştır. Cronbach Alpha iç tutatlık katsayısı kullanılarak ölçeğe ve ölçeğin bileşenlerine ait güvenirlik hesaplanmıştır. AFA sonuçlarına göre belirlenen model DFA ile test edilerek, modele ilişkin Ki-kare $\left(\chi^{2}\right), \chi^{2} / \mathrm{sd}$, RMSEA, RMR, GFI, IFI, NNFI, NFI ve AGFI uyum iyiliği indeksleri incelenmiştir.

\section{Bulgular}

Ölçek maddelerine ilişkin madde toplam test korelasyonları ve ölçeğin faktör yapısına Tablo 1'de yer verilmiştir.

Tablo 1. LEGO Robotik Öğretim Uygulamalarının Kabulü Ölçeğinin Güvenirlik, Madde Toplam Test Korelasyonu ve Faktör Analizi Sonuçları

\begin{tabular}{ccccc}
\hline $\begin{array}{c}\text { Madde } \\
\text { No }\end{array}$ & $\begin{array}{c}\text { Madde Toplam Test } \\
\text { Korelasyonu }\end{array}$ & $\mathbf{1}$ & $\mathbf{2}$ & $\mathbf{4}$ \\
\hline M1 &, 740 &, 719 &,- 332 & \\
M2 &, 813 &, 814 & & \\
M3 &, 819 &, 813 & & \\
M4 &, 796 &, 802 & & \\
M5 &, 814 &, 746 & & \\
M6 &, 743 &, 747 & & \\
M7 &, 770 &, 770 & & \\
M8 &, 784 &, 721 & & \\
M9 &, 715 &, 615 &, 503 & \\
M10 &, 642 &, 752 & & \\
M11 &, 734 &, 721 & & \\
M12 &, 739 &, 624 &, 522 & \\
M13 &, 654 &, 573 &, 638 & \\
M14 &, 611 &, 784 & & \\
M15 &, 787 &, 815 & & \\
M16 &, 721 &, 829 & & \\
M17 &, 756 &, 417 & & \\
M18 &, 771 &, 775 & & \\
M19 &, 394 &, 810 & & \\
M20 &, 725 &, 788 & & \\
M21 &, 763 &, 788 & & \\
M22 &, 417 &, 789 & & \\
M23 &, 761 & & & \\
\hline
\end{tabular}




\begin{tabular}{|c|c|c|c|c|c|}
\hline M24 & ,790 & ,774 & & & \\
\hline M25 & ,790 & ,828 & & & \\
\hline M26 & ,782 & ,444 & & ,618 & ,377 \\
\hline$\overline{\text { Özdeğer }}$ & & 14,268 & 1,533 & 1,358 & 1,067 \\
\hline Açıklanan varyans & & 54,867 & 5,896 & 5,224 & 4,106 \\
\hline Güvenirlik & & ,965 & & & \\
\hline
\end{tabular}

Tablo 1 incelendiğinde, ölçeğin deneme formunun iç tutarlılık katsayısı .965 olduğu görülmektedir. Ölçeğin özdeğer istatistiği incelendiğinde, özdeğeri 1'den büyük olan 4 faktör olduğu görülmektedir. Özdeğeri 14,268 olaran 1. faktör, varyansın $\% 54,867$ ' sini açılarken özdeğeri 1,533 olan 2 . faktör ise varyansın $\% 5,896$ 'sını açıklamaktadır. Döndürülmemiş sonuçlar için özdeğerler ve faktör yükleri birlikte incelendiğinde 1. ve 2. faktörün özdeğerleri arasındaki farktan dolayı ölçeğin tek boyutlu bir yapıda olduğu söylenebilir. Ölçeğin tek faktörlü olduğunun göstergeleri olarak (1) ölçeğin deneme formunun iç tutarlılık katsayısının (.965) yüksek olması, (2) 1. faktörün tek başına açıkladığı varyans oranının yüksek olması ve (3) 1 . faktörün özdeğerinin 2. faktörün yaklaşık 10 katı olması kabul edilebilir. Faktör yük dağılımını daha net ortaya koymak için varimax döndürme yöntemi kullanılmıştır.

Varimax döndürme yöntemine dayalı AFA analizi sonuçları ölçeğin tek faktörlü üç bileşenli bir yapıya sahip olduğunu göstermiş̧tir. Ölçeğin madde toplam test korelasyonlarına, faktör yapısına ve Cronbach Alpha güvenirlik katsayısına Tablo 2'de yer verilmiştir.

Tablo 2. Varimax Döndürme Yöntemine Göre LEGO Robotik Öğretim Uygulamalarının Kabulü Ölçeğinin Faktör Yükü Dağılımı

Tablo 2 incelendiğinde, madde toplam test korelasyonlarının yüksek olduğu görülmektedir. Dört bileşen toplam varyansın \%78.665'ini açıklamaktadır. Birinci faktörün değişkenin \%60.738'ini tek başına açıklaması ve ölçeğin tamamına yönelik hesaplanan Cronbach Alpha katsayısının 956 bulunması maddelerin homojen bir yapıya sahip olduğunun göstergesidir. Ayrıca özdeğer istatistik değerleri incelendiğinde, 1. faktörün özdeğerinin 9,718 olması ve 2. faktörün özdeğerinden yaklaşık sekiz kat fazla olması ölçeğin tek faktörlü dört bileşenli bir yapıya sahip olduğunu göstermektedir.

Ölçeğin bileşenlerine ilişkin Cronbach Alpha güvenirlik katsayıları ise sırasıyla .924; .929; .834 ve .915 olarak hesaplanmıştır. Ölçeğin bütününe ilişkin hesaplanan Cronbach Alpha katsayısı .956 bulunmuştur. Cronbach Alpha değerinin .70 ve üstü olması durumunda test edilen ölçeğin güvenilir olduğu kabul edilmektedir (Sipahi ve diğerleri, 2010). Bu bağlamda da bileşenlerine ve ölçeğin tamamına ilişkin elde edilen güvenirlik değerleri ölçeğin LEGO robotik öğretim uygulamalarının ne derece kabul edildiğini belirlemeye yönelik güvenilir bir veri toplama aracı olduğunu göstermektedir. Ölçeğin geçerliğinin kanıtı olarak Pearson Momentler Çarpımı Korelasyon katsayıları hesaplanmış olup, ölçek bileşenlerinin kendi aralarında ve ölçek toplam puanıyla olan ilişkileri Tablo 3 'te yer almaktadır.

Tablo 3. Bileşen ve Toplam Puan Korelasyonları

\begin{tabular}{llllll}
\hline & 1. Bileșen & 2. Bileşen & 3. Bileşen & 4. Bileşen & $\begin{array}{l}\text { Toplam } \\
\text { Puan }\end{array}$ \\
\hline 1. Bileșen & $1 * *$ & $.735^{* *}$ & $.642^{* *}$ & $.731^{* *}$ & $.885^{* *}$ \\
2. Bileșen & $.735^{* *}$ & $1 * *$ & $.686^{* *}$ & $.762^{* *}$ & $.921^{* *}$ \\
3. Bileșen & $.642^{* *}$ & $.686^{* *}$ & $16^{* *}$ & $.646^{* *}$ & $.837^{* *}$ \\
4. Bileșen & $.731^{* *}$ & $.762^{* *}$ & $.646^{* *}$ & $1 * *$ & $.875^{* *}$ \\
\hline
\end{tabular}

Tablo 3'te görüldüğü gibi bileşenler birbirleriyle ve toplam puanla pozitif yönde anlamlı ilişki göstermektedir. $\mathrm{Bu}$ bulgular ölçeğin tek faktörlü dört bileşenli bir yapıya sahip olduğunu ortaya koymaktadır. Ölçeğin son hali 16 maddeden oluşmaktadır. Ölçekte yer alan maddelerin bileşenlere göre dağılımı incelendiğinde birinci bileşenin; 2 , 3,4 , ve 5. maddelerden oluştuğu görülmektedir. Bu bileşen algılanan fayda olarak adlandırılmıştır. Çünkü bu bileşende yer alan maddeler LEGO robotik öğretim uygulamalarının öğrenme-öğretme sürecinde kullanımının sağladı̆̆ı faydaları yansıtmaktadır. Bu bileşende yer alan maddeler aşağıdaki gibidir:

Madde 2. LEGO Mindstorms kullanmak derslerdeki verimliliğimi arttırır.

Madde 3. LEGO Mindstorms kullanmak derslerdeki performansımı arttırır. 
Madde 4. LEGO Mindstorms derslerdeki etkinliğimi arttırır.

Madde5. LEGO Mindstorms kullanmayı okul yaşantım ile ilgili işlerde yararlı buluyorum.

İkinci bileşende 21., 23., 24., 25. ve 26. maddeler yer almaktadır. Bu bileşen kullanıma yönelik niyet olarak adlandırılmıştır. Bu bileşende yer alan maddeler LEGO robotik öğretim uygulamalarının öğrenme-öğretme sürecinde kullanımına ilişkin niyeti göstermektedir. Bu bileşende yer alan maddeler aşağıdaki gibidir:

Madde 21. Derslerimde LEGO Mindstorms uygulamaları yapmak istiyorum.

Madde 23. Gelecekte derslerimde LEGO Mindstorms uygulamaları yapmayı isterim.

Madde 24. Arkadaşlarımı da LEGO Mindstorms uygulamaları yapmaları teşvik edeceğim.

Madde 25. Öğrenim ve öğretmenlik hayatımda LEGO Mindstorms uygulamalarına da yer vereceğim.

Madde 26. Problemlerin çözümünde LEGO Mindstorms uygulamalarını kullanacağım.

Üçüncü bileşen 10., 11., 12. ve 13. maddelerden oluşmaktadır. Bu bileşen algılanan kullanım kolaylığı olarak adlandırılmıştır. $\mathrm{Bu}$ bileşende yer alan maddelerle LEGO robotik öğretim uygulamalarının öğrenme-öğretme sürecinde kullanımında harcanan çabanın az olacağı vurgulanmaktadır. Bu bileşende yer alan maddeler aşağıdaki gibidir:

Madde 10. LEGO Mindstorms uygulamalarını öğrenmek benim için kolaydır.

Madde 11. LEGO Mindstorms uygulamaları ile derslerimi kolayca yaparım.

Madde 12. LEGO Mindstorms uygulamasındaki herhangi bir problemin çözümü için yapmam gerekenler net ve anlaşilırdır.

Madde 13. LEGO Mindstorms uygulamalarında kolayca ustalaşacağımı düşünüyorum.

Dördüncü bileşen 16., 17. ve 18. maddelerden oluşmaktadır. Bu bileşen kullanıma yönelik tutum olarak adlandırılmıştır. $\mathrm{Bu}$ bileşende yer alan maddeler LEGO robotik öğretim uygulamalarının öğrenme-öğretme sürecinde kullanımına ilişkin tutumu yansıtan ifadelerdir. Bu bileşende yer alan maddeler aşağıdaki gibidir:

Madde 16. Derslerimde LEGO Mindstorms uygulamaları yapmak eğlenceli olabilir.

Madde 17. Derslerimde LEGO Mindstorms uygulamaları yapmak hoşuma gider.

Madde 18. Derslerimde LEGO Mindstorms uygulamaları yapmak beni mutlu eder.

AFA sonuçlarına göre belirlenen model DFA ile test edilmiş; analizler sonucunda ise modele ait uyum iyiliği indekslerine bakılmıştır. Ki-kare $(\chi 2), \chi 2 / s d$, RMSEA, RMR, GFI ve AGFI istatistikleri DFA ile model veri uyumuna ilişkin hesaplanan istatistiklerden en yaygın kullanılanlardır (Duyan ve Gelbal, 2008). Modele ilişkin

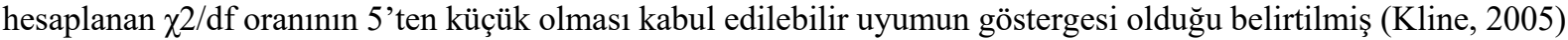
ve $\chi^{2 / \mathrm{df}}$ değerinin 5 'in altında olması önerilmiştir (Hooper, Coughlan ve Mullen, 2008). Ayrıca GFI değerinin 0.85 'ten, AGFI değerinin 0.80 'den büyük ve RMR ile RMSEA değerlerinin 0.10'dan küçük olması model veri uyumu için kabul edilebilir alt sınırlar olarak görülmektedir (Anderson ve Gerbing, 1984; Cole, 1987, Meydan ve Şeşen, 2011). DFA ile model veri uyumuna ilişkin hesaplanan istatistiklerden RMSEA (.086), NFI ve NNFI (.93), PNFI (.76), CFI (.94), GFI (.88), AGFI (.84), ki-kare/serbestlik derecesi (3.65) olarak hesaplanmıştır. Modele ilişkin elde edilen iyilik uyum indekslerinden modelin gözlenen yapıya uygun olduğu söylenebilir. LEGO robotik öğretim uygulamalarının öğrenme-öğretme sürecinde kullanımının kabulü modeline ilişkin path diyagramı Şekil 1 'de sunulmuştur. 


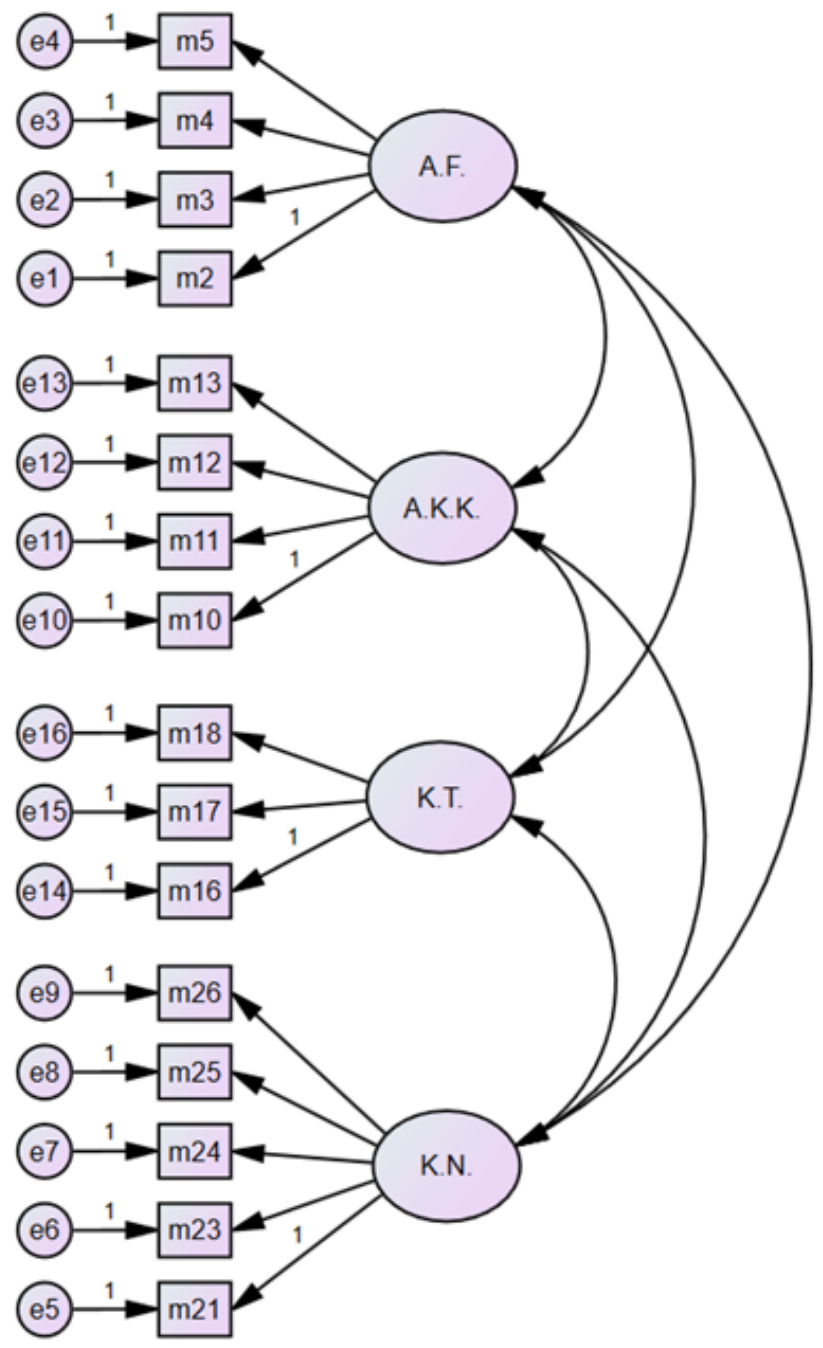

Şekil 1. LEGO robotik öğretim uygulamalarının kabulü modeli yol diyagramı

\section{Tartışma, Sonuç ve Öneriler}

Araştırma kapsamında öğretmen adaylarının LEGO robotik öğretim uygulamalarını kabul durumlarını belirlemeyi sağlayan geçerli ve güvenirliği test edilen bir ölçek geliştirilmiştir. Ölçek geliştirme çalışmasında 2016-2017 öğretim yllında Bartın Üniversitesi Eğitim Fakültesinde 3. ve 4. Sınıfta öğrenim gören öğretmen adaylarından veri toplanmıştır. Veri toplama süreci öncesinde teknoloji kabul modeline ve LEGO robotik öğretim uygulamalarına iliş̧kin alanyazın taraması yapılarak ölçek denem formu için maddeler yazılmıştır. Deneme formundaki ölçek maddelerine ilişkin Bilgisayar ve Öğretim Teknolojileri Eğitimi, Eğitim Bilimleri ve Türkçe Eğitimi Bölümlerindeki uzmanlardan uzman görüşü alınmıştır. Bu bağlamda uzmanlardan ölçek maddelerini, maddelerin ölçülmek istenen değişkeni kapsama durumları, maddelerin ölçülmek istenen faktör ya da faktörlere uygunlukları, maddelerin anlaşılır olması ve açık olarak ifade edilme durumu, maddelerin çalışma grubuna uygunluğu, vb. değiş̧kenler açısından değerlendirmeleri istenmiş, elde edilen dönüt ve düzeltme işlemleri ardından ölçeğin deneme formuna son şekli verilmiştir. Ölçek formunun çalışma grubuna uygulanması sürecinden önce, çalışma grubunun tamamına LEGO Mindstorms EV3 seti ve LEGO Mindstorms EV3 setinin öğrenme öğretme süreçlerinde nasıl kullanılabileceğine ilişsin temalarda video gösterimiyle tanıtım yapılmış, öğretmen adaylarının ilgili konulardaki soruları yanıtlanmıştır.

AFA çalı̧̧maları sonucunda, açıklanan varyans değerinin \%78.665 olduğu görülmektedir. Elde edilen açıklayıcı varyans değeri (\%78.665) ölçeğin faktör yapısına ilişkin karar vermede yeterli görülmüştür. Birinci faktörün tek başına değişkenin \%60.738'ini açıklamasına dayanarak, ölçeğin tek faktörlü bir yapı (tek faktörlü- 
dört bileşenli) sergilediği söylenebilir. Ayrıca özdeğer istatistik değerleri incelendiğinde, birinci faktörün özdeğerinin 9,718 olması ve ikinci faktörün özdeğerinden yaklaşık sekiz kat fazla olması ölçeğin tek faktörlü dört bileşenli bir yapıya sahip olduğunu göstermektedir. Ölçeğin bütününe ilişkin hesaplanan Cronbach Alpha güvenirlik katsayısı .956; ölçeğin bileşenlerine ilişkin Cronbach Alpha güvenirlik katsayıları ise sırasıyla .924; $.929 ; .834$ ve .915 olarak hesaplanmıştır. Bu bağlamda da bileşenlerine ve ölçeğin tamamına ilişkin elde edilen güvenirlik değerleri ölçeğin LEGO robotik öğretim uygulamalarının ne derece kabul edildiğini belirlemeye yönelik güvenilir bir veri toplama aracı olduğunu göstermektedir. Pearson Momentler Çarpımı Korelasyon katsayıları hesaplanarak ölçek bileşenlerinin kendi arasında ve ölçeğin toplam puanıyla olan ilişkileri incelendiğinde, bileşenlerin kendi aralarında ve ölçeğin toplam puanıyla olumlu yönde anlamlı ilişki gösterdiği açıkça görülmektedir.

Araştırmada açımlayıcı faktör analizinden sonra tespit edilen modelin denenmesi için doğrulayıcı faktör analizi gerçekleştirilmiştir. Doğrulayıcı faktör analizi ile model veri uyumuna ilişkin hesaplanan istatistiklerden RMSEA (.086), NFI ve NNFI (.93), PNFI (.76), CFI (.94), GFI (.88), AGFI (.84), ki-kare/serbestlik derecesi (3.65) olarak hesaplanmıştır. Modele ilişkin elde edilen iyilik uyum indekslerinden modelin gözlenen yapıya uygun olduğu söylenebilir.

Açımlayıcı ve doğrulayıcı faktör analizi çalışmaları sonucunda LEGO robotik öğretim uygulamalarının kabulü ölçeğinin 16 maddeden oluşan tek faktörlü dört bileşenli bir yapı sergilediği sonucuna varılmıştır. Teknoloji kabul modeli bileşenleri dikkate alınarak ölçek bileşenleri algılanan fayda, algılanan kullanım kolaylığı, tutum ve kullanıma yönelik niyet olarak adlandırılmıştır.

Teknoloji destekli öğretim uygulamalarının sınıfların ayrılmaz parçası olduğu günümüz eğitim anlayışında LEGO robotik öğretim uygulamalarıyla öğrenme öğretme sürecine yön vermek kaçınılmazdır. LEGO robotik öğretim uygulamalarının ilkokuldan üniversite düzeyine kadar eğitimin her aşamasında ve her disiplin alanında işlevsel olarak kullanılabilir olması nedeniyle bu uygulamaların öğretmenler tarafından benimsenmesi ve öğretmenlerin bu uygulamalarla öğretimi nitelikleştirmesi beklenmektedir. Bu beklentinin gerçekleşme durumuna ilişkin güvenilir bilgi elde etmek için öğretmen ya da öğretmen adaylarının bu uygulamaları kabul etme durumlarını ölçen bir veri toplama aracına ihtiyaç duyulmaktadır. Dolayısıyla LEGO robotik öğretim uygulamalarının kabulü ölçeğiyle öğretmen ya da öğretmen adaylarının öğretim uygulamalarında LEGO robotik uygulamaları benimseme ve kullanma durumlarına ilişkin bilgi edinilmesi kolaylaşacaktır. Ayrıca eğitim fakültelerinde LEGO robotik öğretim uygulamalarıyla desteklenen öğretim sürecinin öğretmen adaylarının bu tür uygulamaları kabul ederek öğretmenlik mesleğine başladıklarında bu tür öğretim uygulamalara yer verme durumlarına ilişkin bilgi edinmek adına ve bu tür bilimsel çalışmaları gerçekleştirmede araştırmacılar tarafından geliştirilen ölçek işlevsel olarak kullanılabilir. Ayrıca öğretmen ya da öğretmen adaylarının LEGO robotik öğretim uygulamalarını kabul durumlarına doğrudan ya da dolaylı etkisi olduğunu düşünülen değişkenler kapsamında üretilen yapısal modeller test edilebilir. Ayrıca bu ölçek öğrenci merkezli eğitim anlayışıyla LEGO uygulamalarıyla robot tasarlamaları ve tasarladıkları robotu öğrenme amaçlı kullanmaları sağlanan farklı eğitim seviyesindeki ögrenenlere de uyarlanabilir.

\section{Teşekkür ve Bilgilendirme}

Bu çalışma Bartın Üniversitesi Bilimsel Araştırma Projeleri Koordinatörlüğü tarafından desteklenmiştir.(Proje No: 2016-SOS-A-014). 


\section{References}

Adams Becker, S., Freeman, A., Giesinger Hall, C., Cummins, M., \& Yuhnke, B. (2016). NMC/CoSN horizon report: 2016 K-12 edition. Austin, Texas: The New Media Consortium.

Alkan, C. (2011). Eğitim Teknolojisi [Educational Technology). Ankara: Anı Publishing.

Anderson, J. C. , \& Gerbing, D.W. (1984). The effect of sampling error on convergence, improper solutions, and goodness of fit indices for maximum likelihood comfirmatory factor analysis. Psychometrika, 49, 155-173, Doi: 10.1007/BF02294170.

Aufderheide, D., Krybus, W. , \& Witkowski, U. (2012). Experiences with LEGO MINDSTORMS as an Embedded and Robotics Platform within the Undergraduate Curriculum. Advances in Autonomous Robotics. 185-196. Bristol: Springer.

Beisser, S. R. (2005). An Examination of gender differences in elementary constructionist classrooms using Lego/Logo instruction. Computers in the Schools: Interdisciplinary Journal of Practice, Theory, and Applied Research, 22(3-4), 7-19.

Benitti, F. B. V. (2012). Exploring the educational potential of robotics in school: A systematic review. Computers \& Education, 58, 978-988. doi:10.1016/j.compedu.2011.10.006.

Bryman, A. , \& Cramer, D. (1999). Quantitative sata analysis with SPSS release 8 for Windows: A guide for social scientist. London: Routledge.

Büyüköztürk, Ş. (2002). Faktör analizi: Temel kavramlar ve ölçek geliştirmede kullanımı [Factor analysis: Basic concepts and use in developing scale]. Kuram ve Uygulamada Ĕgitim Yönetimi, 32, 470-488.

Castledine, A. , \& Chalmers, C. (2011). LEGO robotics: An authentic problem solving tool? Design and Technology Education: An International Journal, 16(3), 19-27.

Catlin, D. (2012). Maximising the effectiveness of educational robotics through the use of assessment fot learning methodologies. Proceedings of 3rd International workshop teaching Robotics, Teaching with Robotics, Integrating Robotics in School Curriculum, (s. 2-11). Riva del Garda (Trento, Italy). 09.11.2016 tarihinde http://www.terecop.eu/TRTWR2012/trtwr2012_submission_01.pdf adresinden alınd1

Chesney, T. (2006). An acceptance model for useful and fun information systems. An Interdisciplinary Journal on Humans in ICT Environments, 2(2), 225-235. doi:dx.doi.org/10.17011/ht/urn.2006520

Coakes, S. J. (2005). SPSS: Analysis without anguish: Version 12.0 for Windows. Melbourne: John Wiley and Sons.

Cole, D. A. (1987). Utility of confirmatory factor analysis in test validation research. Journal of Consulting and Clinical Psychology, 55, 1019-1031.

Dastjerdi, N. B. (2016). Factors affecting ICT adoption among distance education students based on the technology acceptance model - A case study at a distance education university in Iran. International Education Studies, $9(2), 73-80$.

Davis, F. (1989). Perceived usefullness, perceived ease of use, and user acceptance of information technology. Management Information Systems Quarterly, 13(3), 319-340.

Davis, F. (1993). User acceptance of information technology: system characteristics, user perceptions and behavioral impacts. International Journal of Man-Machine Studies, 38(3), 475-487.

Duyan, V., \& Gelbal, S. (2008). Barnett çocuk sevme ölçeği'ni Türkçe’ye uyarlama çalışması [Barnett's study of adapting the scale of child-loving scale to Turkish]. Eğitim ve Bilim, 33(148), 40-48. 
Erbaş, Ç., \& Demirer, V. (2015). Eğitimde sanal ve arttırılmış gerçeklik uygulamaları [Virtual and augmented reality applications in education]. In B. Akkoyunlu, A. İşman, \& H. F. Odabaşı, Eğitim Teknolojileri Okumaları [Educational Technology Readings] 2015. 131-148. Ankara: TOJET - The Turkish Online Journal of Educational Technology.

Gable, R. K. (1986). Instrument development in the affective domain. Boston: Kluwer-Nijhoff Publishing.

Heerink, M., Krose, B. J., Evers, V. ve Wielinga, B. J. (2006). Studying the acceptance of a robotic agent by elderly users. International Journal of ARM, 7(3), 33-43.

Hsia, J. (2016). The effects of locus of control on university students' mobile learning adoption. Journal of Computing in Higher Education, 28, 1-17. doi:10.1007/s12528-015-9103-8

Johnson, L., Adams Becker, S., Cummins, M., Estrada, V., Freeman, A., \& Hall, C. (2016). NMC horizon report: 2016 higher education edition. Austin, Texas: The New Media Consortium.

Johnson, L., Adams Becker, S., Estrada, V., \& Freeman, A. (2015). NMC horizon report: 2015 higher education edition. Austin, Texas: The New Media Consortium.

Karagiorgi, Y., \& Symeou, L. (2005). Translating constructivism into instructional design: Potential and limitations. Educational Technology \& Society, 8(1), 17-27.

Kazez, H., \& Genç, Z. (2016). İlkokul matematik öğretiminde yeni bir yaklaşım: Lego MoretoMath [A new approach in primary school mathematics teaching: Lego MoretoMath]. Journal of Instructional Technologies \& Teacher Education, 5(2), 59-71.

Kazimoglu, C., Kiernan, M., Bacon, L., \& Mackinnon, L. (2012). A serious game for developing computational thinking and learning introductory computer programming. Procedia-Social and Behavioral Sciences, 47, 1991-1999. doi:10.1016/j.sbspro.2012.06.938

Khee, C.M., Wei, G.W., \& Jamaluddin, S.A. (2014). Students' perception towards lecture capture based on the technology acceptance model. Procedia-Social and Behavioral Sciences, 123, 461-469.

Kline, R. B. (2005). Principles and practice of structural equation modeling. NY: Guilford Publications, Inc.

Koehler, M. J., Mishra, P., Kereluik, K., Shin, T. S., \& Graham, C. R. (2014). The technological pedagogical content knowledge framework. In J. M. Spector, M. D. Merrill, J. Elen., \& M. J. Bishop, Handbook of Research on Educational Communications and Technology (Fourth Edition b., 101-111). New York: Springer.

McKnight, L. (2015). Still in the LEGO (LEGOS) room: female teachers designing curriculum around girls' popular culture for the coeducational classroom in Australia. Gender and Education, 27(7), 909-927. doi:10.1080/09540253.2015.1096920

MEB. (2016). Bilgisayar Bilimi Dersi Öğretim Programı Kur 1 - Kur 2 [Computer Science Teaching Program Curriculum 1 - Curriculum 2]. Ankara.

Murillo, A. C., Mosteo, A. R., Castellanos, J. A., \& Montano, L. (2011). A practical mobile robotics engineering course using LEGO Mindstorms. Research and Education in Robotics - EUROBOT 2011. 221-235. Praque: Springer.

Murphy, K. R., \& Davidshofer, C. O. (1998). Pschological testing principles and applications. Fourth Edition. New Jersey: Prentice Hall.

NMC. (2017). NMC horizon report preview: 2017 higher education edition. The New Media Consortium. 20.12.2016 tarihinde http://cdn.nmc.org/media/2017-nmc-horizon-report-he-preview.pdf adresinden alınd1 
Noar, S. M. (2003). The role of structural equation modeling in scale development. Structural Equation Modeling: A Multidisciplinary Journal, 10(4), 622-647.

Ortiz, A. (2015). Examining students' proportional reasoning strategy levels as evidence of the impact of an integrated LEGO robotics and mathematics learning experience. Journal of Technology Education, 26(2), 4669.

Ospennikova, E., Ershov, M., \& Iljin, I. (2015). Educational robotics as an inovative educational technology. Procedia - Social and Behavioral Sciences, 214, 18-26.

Özdoğru, E. (2013). Fiziksel olaylar öğrenme alanı için LEGO program tabanlı fen ve teknoloji eğitiminin ögrencilerin akademik başarılarına, bilimsel süreç becerilerine ve fen ve teknoloji dersine yönelik tutumlarına etkisi [The effect of Lego programme based science and technology education on the students academic achievement, science process skills and their attitudes toward Science and Technology course for pyhsical facts learning field]. Unpublished master dissertation, Dokuz Eylül University, Institute of Education Sciences

Pala, F., \& Erdem, M. (2015). Çevrimiçi öğrenme ortamları ve katılım [Online learning environments and participation]. In B. Akkoyunlu, A. İşman ve H. F. Odabaşı, Eğitim Teknolojileri Okumaları [Educational Technology Readings]. 2015. 213-232. Ankara: TOJET - The Turkish Online Journal of Educational Technology.

Prensky, M. (2001). Digital natives, digital immigrants. On The Horizon, 9(5).

Prensky, M. (2010). Teaching digital natives: Partnering for real learning. Thousand Oaks, California: Corvin.

Shih, B., Chen, C., Chen, C., \& Hsin, I. (2012). Using Lego NXT to explore scientific literacy in disaster prevention and rescue systems. Journal of the International Society for the Prevention and Mitigation of Natural Hazards, 64(1), 153-171. doi:10.1007/s11069-012-0233-2

Shih, B., Shih, C., Li, C., Chen, T., Chen, Y., \& Chen, C. (2011). Elementary school student's acceptance of Lego NXT: The technology acceptance model, a preliminary investigation. International Journal of the Physical Sciences, 5057-5063. doi:10.5897/IJPS11.708

Somyürek, S. (2015). An effective educational tool construction kits for fun and meaningful learning. International Journal of Technology and Design Education, 25, s. 25-41.

Spector, J. M. (2016). Foundations of educational technology: Integrative approaches and interdisciplinary perspectives (Second Edition b.). New York: Rouhledge.

Strawhacker, A., \& Bers, M. (2015). "I want my robot to look for food": Comparing kindergartner's programming comprehension using tangible, graphic, and hybrid user interfaces. International Journal of Technology and Design Education, 25, 293-319.

Sungur, K. (2013). Yöntem olarak mühendislik-dizayna ve ders materyali olarak legolara öğretmen ve öğretmen adaylarının bakış açılarının incelenmesi [Investigation of in service and pre service science teachers perspectives about engineering-design as an instructional method and legos as an instructional material]. Unpublished master dissertation, Erciyes University, Institute of Education Sciences.

Sümer, N. (2000). Yapısal eşitlik modelleri [Structural equation models]. Türk Psikoloji Yazılarl, 3(6), 49-74.

Tabachnick, B. G., \& Fidell, L. S. (2001). Using multivariate statistics. Needham Heights, Allyn \& Bacon.

Teo, T. (2010). A path analysis of pre-service teachers' attitudes to computer use: Applying and extending the technology acceptance model in an educational context. Interactive Learning Environments, 18(1), 65-79.

Uğur Erdoğmuş, F., \& Çağıltay, K. (2013). Türkiye'de eğitim teknolojileri alanında yayımlanan yüksek lisans ve doktora tezlerinde genel eğilimler [Master and doctoral dissertations published in the field of general trends in 
educational technology in Turkey]. In K. Çağıltay \& Y. Göktaş, Öğretim Teknolojilerinin Temelleri: Teoriler, Araştırmalar, Eğilimler [The Basics of Instructional Technologies: Theories, Research, Trends] (279-290). Ankara: Pegem Academy.

Walsh, W. B., \& Betz, N. E. (1995). Tests and Assessment. Third Edition. New Jersey: Prentice Hall. 